\title{
A New Cold-Active Glucose Oxidase From Penicillium: High-Level Expression and Application in Fish Preservation
}

\author{
Mingxue Yuan, Chen Ning, Suxiao Yang, Qingping Liang, Haijin Mou* and Zhemin Liu* \\ College of Food Science and Engineering, Ocean University of China, Qingdao, China
}

Glucose oxidase (GOx) with high enzyme activity at low temperature $\left(4^{\circ} \mathrm{C}\right)$ is potentially useful for food preservation, especially for aquatic products preservation. A cold-active GOx with approximately 83\% similarity to known protein sequences, was isolated from Penicillium sp. MX3343 and expressed in Pichia pastoris X33. Through high cell density fermentation, the yield of recombinant enzyme (named GOxP 5 ) reached $458.6 \mathrm{U} / \mathrm{mL}$. GOxP 5 showed optimal activity at $30^{\circ} \mathrm{C}$ and $\mathrm{pH} 5.5$, and was stable at a broad $\mathrm{pH}$

OPEN ACCESS

Edited by:

Jörg Hummerjohann,

Agroscope, Switzerland

Reviewed by:

Dawei Yu,

Jiangnan University, China

Pascal Degraeve,

Université Lyon 1, France

${ }^{*}$ Correspondence:

Haijin Mou

mousun@ouc.edu.cn

Zhemin Liu

ocean2013@126.com

Specialty section:

This article was submitted to

Food Microbiology,

a section of the journal

Frontiers in Microbiology

Received: 14 September 2020 Accepted: 03 November 2020

Published: 23 November 2020

Citation:

Yuan $M$,

Ning C, Yang S, Liang Q, Mou $H$ and

Liu Z (2020) A New Cold-Active

Glucose Oxidase From Penicillium:

High-Level Expression

and Application in Fish Preservation.

Front. Microbiol. 11:606007.

doi: 10.3389/fmicb.2020.606007 range from $\mathrm{pH} 2-6$. Moreover, $\mathrm{GOXP}_{5}$ could maintain $72 \%$ maximum activity at $4^{\circ} \mathrm{C}$, suggesting its application for the preservation of aquatic products at low-temperatures. Importantly, GOxP 5 showed a good antimicrobial effect against common fish pathogenic bacteria (Listeria monocytogenes and Vibrio parahaemolyticus). Moreover, sensory, microbiological (total bacterial count), and physicochemical (total volatile basic nitrogen and $\mathrm{pH}$ ) systematic analyses proved $\mathrm{GOxP}_{5}$ to be an excellent freshness preserving agent in the context of the grass carp. These favorable enzymatic properties of $\mathrm{GOxP}_{5}$ make it potentially useful in food biopreservation, and the effect was better compared to the commonly used chemical preservatives.

Keywords: glucose oxidase, cold-active, Pichia pastoris, high-efficiency expression, antimicrobial, fish preservation

\section{INTRODUCTION}

Glucose oxidase (GOx; glucose aerodehydrogenase; E.C.1.1.3.4.) is a flavoprotein that catalyzes the dehydrogenation of $\beta$-D-glucose to gluconic acid and hydrogen peroxide $\left(\mathrm{H}_{2} \mathrm{O}_{2}\right)$ using molecular oxygen as an electron acceptor and FAD acts as a redox carrier (Hatzinikolaou et al., 1996; Bankar et al., 2009). GOx attracted much attention due to its wide applications in the biosensors, biofuel, chemical, beverage and animal feed industries, as well as in the food preservation field (Field et al., 1986; Gao et al., 2012; Tang et al., 2016). Such applications include its use in bread to strengthen gluten, in glucose sensors to monitor the environment, in feed to improve the intestinal acid digestive environment, and even in food preservation to extend shelf life.

Abbreviations: GOx, glucose oxidase; FAD, flavin adenine dinucleotide; CTAB, cetyl trimethyl ammonium bromide; SDSPAGE, Sodium dodecyl sulfate-polyacrylamide gel electrophoresis; ZOI, zone of inhibition; TBC, total bacterial count; TVB$\mathrm{N}$, total volatile basic nitrogen; MIC, minimum inhibitory concentration; $\mathrm{MBC}$, the minimum bactericidal concentration. 
In the food preservation industry, biopreservatives such as chitosan (Jeon et al., 2002), antibacterial peptides (e.g., nisin), lysozyme (Sun et al., 2020), and glucose oxidase (Dondero et al., 1993), have a safer and better effect on delaying the spoilage time of food compared to traditional chemical preservatives. GOx was used as a preserving agent with a significant antibacterial effect against Pseudomonas fragi (Yoo and Rand, 1995), enterotoxigenic Escherichia coli, L. monocytogenes, and V. parahemolyticus in aquatic products (Massa et al., 2001); of note, these bacteria are associated with food contamination. However, the applications of GOx in the context of the preservation of aquatic products are limited owing to the absence of cold-active enzymes. Importantly, GOx are widely found in nature and have been purified from different microbial sources for commercial applications; these sources include fungi such as Penicillium and Aspergillus, especially $P$. amagasakiense and A. niger (Guo et al., 2010; Gao et al., 2012). Of note, GOx from Penicillium showed better catalytic efficiency for glucose oxidation (Kusai et al., 1960). However, few of the reported GOx could retain the required enzymatic activity at $4^{\circ} \mathrm{C}$.

An ideal GOx for the preservation of aquatic products should possess three properties: cold-active ability, acid and alkali resistance, and highly specific activity. Studies have reported the use of GOx to extend shelf life of shrimp products. Dondero et al. (1993) found that shrimps maintained in a GOx/Catalase/glucose solution could be stored for up to 13 days before being refrigerated compared to 6 days for control shrimp preparations. Moreover, Xu et al. (2018) improved the quality and freshness of shrimps subjected to cold storage via the treatment with a novel GOx (12.5 U/mL) from Bacillus sp. CAMT22370. However, little information about the use of GOx to preserve fish is available. As a freshwater fish, grass carp is easily susceptible to spoilage; therefore, it is particularly important to maintain its freshness via the use of preservatives such as GOx.

Here, a new gene encoding a cold-active GOx from Penicillium sp. MX3343 was acquired, and expressed heterologously in Pichia pastoris (Macauley-Patrick et al., 2005). The biochemical characteristics of the recombinant enzyme were analyzed, and the yield of GOx was significantly enlarged via high cell fermentation. Moreover, for better evaluating its potential in preserving aquatic products, two common fish pathogens were selected to test its antibacterial effect. Subsequently, a fresh-keeping experiment using grass carp at $4^{\circ} \mathrm{C}$ was performed to prove its potential as a low-temperature food preservative agent.

\section{MATERIALS AND METHODS}

\section{Materials}

The GOx gene was cloned from Penicillium sp. MX3343, which we isolated and identified from soil. The pPICZ $\alpha$ A was used as an expression vector to construct recombinant plasmids with coding genes ( $\mathrm{pPICZ} \alpha \mathrm{A}-\mathrm{GOxP}_{5}, \mathrm{pPICZ} \alpha \mathrm{A}$-proGOxP ${ }_{5}$ ). Escherichia coli DH5 $\alpha$ (Sangong, China) and Pichia pastoris X33 (Invitrogen, United States) were used as the expression and propagation hosts, respectively. All other chemicals in this research were of analytical grade.

\section{Cloning and Sequencing of the GOx Gene}

Genomic DNA was extracted using the CTAB extraction method described by Van Burik et al. (1998) from Penicillium sp. MX3343 culture. The three specific primers, GOxF1, GOxF2, and GOxR (Table 1) were designed and synthesized based on Penicillium GOx transcriptome analysis. Genomic DNA was used as a template, and GOxF1, GOxF2, and GOxR with an annealing temperature of $56^{\circ} \mathrm{C}$ were used as primers for PCR amplification to amplify the full-length sequences of $\mathrm{GOxP}_{5}$ and proGOxP $\mathrm{P}_{5}$. The PCR products were purified, linked to the $\mathrm{pPICZ} \alpha$ A and sent to Beijing Ruiboxingke Co., Ltd. for sequencing. Signal peptides were analyzed using Signal 4.0 Server. A BLAST server ${ }^{1}$ was used for DNA and protein sequence alignment and conserved domain analysis. The $\mathrm{GOxP}_{5}$ nucleotide sequence used in this study was submitted to GenBank (Accession No. MN912809).

\section{High-Level Expression of the GOx Gene and High Cell Density Fermentation}

The recombinant plasmids pPICZ $\alpha$ A-GOxP ${ }_{5}$ and pPICZ $\alpha$ A-proGOxP 5 were linearized using $\mathrm{SacI}$ and transformed into $P$. pastoris X33 using electroporation with a Gene Pulser device (Invitrogen, United States) based on the manufacturer's instructions. Zeocin was used as selection marker, and the liquid-transformed vector amplification (PTVA) method was used to screen multi-copy strains with high enzyme activity (Aw and Polizzi, 2016). The resultant transformants were inoculated into YPD medium containing zeocin and cultivated at $30^{\circ} \mathrm{C}$. With treatment every $12 \mathrm{~h}$ and transfer to the next medium containing a higher concentration of antibiotics. After colonies were observed, they were numbered in order and inoculated into a 48-well-deep plate containing BMGY liquid medium for fermentation. To maintain induction, $100 \%$ (v/v) methanol was added to the growing culture during selection to a final concentration of $1 \%(\mathrm{v} / \mathrm{v})$ every $24 \mathrm{~h}$. The strain with the highest enzyme activity was selected and used in subsequent experiments.

The $\mathrm{GOxP}_{5}$ strain was selected to high cell density fermentation in a $20 \mathrm{~L}$ fermentor. First of all, the strain was cultured based on previous research (Liu et al., 2020a). Secondly, the shake flask culture solution was transferred to the fermenter containing $10.0 \mathrm{~L}$ of basic salt medium and $40 \mathrm{~mL}$ PTM 1 trace salt. The temperature and $\mathrm{pH}$ of the fermentation process were maintained at $30^{\circ} \mathrm{C}$ and 6.0 , and the rotation speed was controlled. Finally, fed-batch process was carried out when the wet cell mass reached $180 \mathrm{~g} / \mathrm{L}$, and the rate was adjusted during the methanol induction stage to keep the dissolved oxygen

\footnotetext{
${ }^{1}$ http://www.ncbi.nlm.nih.gov/BLAST
}

TABLE 1 | Primers used in this study.

\begin{tabular}{ll}
\hline Primers & Sequence $\mathbf{5}^{\prime} \mathbf{-} \mathbf{3}^{\prime}$ \\
\hline GOxF1 & CAGGGCTTCACTCCAGCCG \\
GOxF2 & ATGAAGTCCATCATTCTTGCCTC \\
GOxR & TTAATGATGATGATGATGATGGGGCTTGTAGTCAGCCAGAACA
\end{tabular}


concentration above $25 \%$. The unit of methanol addition rate is $\mathrm{mL} / \mathrm{L} / \mathrm{h}$, which referred to the amount of methanol that needs to be added per hour in a $20 \mathrm{~L}$ fermentor. The wet cell mass, enzyme activity and protein content of the sample were measured at different time points throughout the induction phase.

\section{Purification of $\mathrm{GOXP}_{5}$ and proGOxP}

The fermentation mixture was centrifuged at $10,000 \times \mathrm{g}$ for $10 \mathrm{~min}$ to remove yeast pellet. The fermented supernatant was concentrated and ultrafiltrated by using a $50 \mathrm{kDa}$ cutoff membrane. According to the previous study (Uchima et al., 2012), a Ni-sepharose 6FF column (GE Healthcare, United States) was used to purify the crude enzyme solution sample. SDS-PAGE (12.5\% running gel) was performed to analyze the $\mathrm{GOxP}_{5}$ molecular weight distribution. According to the Bradford (1976), the protein concentration was determined at $595 \mathrm{~nm}$ with bovine serum albumin (BSA) as the standard.

\section{Biochemical Characterization of $\mathrm{GOxP}_{5}$ and proGOXP 5}

The enzyme activity of $\mathrm{GOxP}_{5}$ was determined based on the method in previous research (Guo et al., 2010). After $3 \mathrm{~mL}$ reaction system was incubated in a $30^{\circ} \mathrm{C}$ water bath for $5 \mathrm{~min}$, $0.1 \mathrm{~mL}$ enzyme solution was added, and the absorbance change value in $1 \mathrm{~min}$ was measured at $500 \mathrm{~nm}$. The amount of enzyme required to oxidize $1 \mu \mathrm{mol}$ of $\mathrm{D}$-glucose into $\mathrm{D}$-gluconic acid and $\mathrm{H}_{2} \mathrm{O}_{2}$ per minute is defined as one unit of $\mathrm{GOxP}_{5}$ activity. The optimum temperature for $\mathrm{GOxP}_{5}$ and proGOxP activity was assayed by assessing the relative activities at different temperatures $\left(4-70^{\circ} \mathrm{C}\right)$ in sodium acetate buffer $(50 \mathrm{mM}, \mathrm{pH} 6.0)$. To estimate thermostability, the residual activity of $\mathrm{GOxP}_{5}$ was assayed after preincubation in sodium acetate buffer $(50 \mathrm{mM}, \mathrm{pH}$ $6.0)$ at several temperatures $\left(5-60^{\circ} \mathrm{C}\right)$ for $10 \mathrm{~min}$, followed by cooling on melting ice for $10 \mathrm{~min}$.

The optimum $\mathrm{pH}$ for $\mathrm{GOxP}_{5}$ and proGOxP 5 activity was assayed by three different buffers with used as follows: $\mathrm{pH} 2.0-$ 3.0 (0.05 M glycine- $\mathrm{HCl}$ ), pH 4.0-6.0 (0.05 M NaAc-HAc), and $\mathrm{pH} 7.0-8.0$ (0.05 M Tris- $\mathrm{HCl})$. To investigate $\mathrm{pH}$ stability, $\mathrm{GOxP}_{5}$ was detected after preincubation in different $\mathrm{pH}$ buffers $(\mathrm{pH}$ $2.0-8.0)$ at $25^{\circ} \mathrm{C}$ for $2 \mathrm{~h}$ before assaying for residual activity.

Thirteen metal ions and chemical reagents were selected to investigate their effects on the activity of recombinant $\mathrm{GOxP}_{5}$ and proGOxP 5 based on the method described by our previous study (Liu et al., 2020b). The group without the additional metal ions and chemical reagents was used as the control. In addition, the substrate specificity was analyzed under the conditions of $30^{\circ} \mathrm{C}$ and $\mathrm{pH}$ 6.0. The effect of different substrates on the activity of purified $\mathrm{GOXP}_{5}$ and proGOxP $\mathrm{x}_{5}$ was evaluated by measuring the activity in the presence of $18 \mathrm{mg} / \mathrm{mL}$ of various substrates. The group with glucose was used as the control.

The kinetic parameters of $\mathrm{GOxP}_{5}$ and proGOxP $\mathrm{P}_{5}$ were assayed in $0.1 \mathrm{M}$ sodium phosphate $(\mathrm{pH}$ 6.0) with $\beta$-D-glucose (50$2,000 \mathrm{mM}$ ) as substrate at $30^{\circ} \mathrm{C}$. According to the glucose oxidase determination standard QWSY 01-2010 in China and the study by Guo et al. (2010), the reaction was measured within $2 \mathrm{~min}$ with sufficient oxygen. The data were determined by fitting the Michaelis-Menten plot using non-linear regression with the software Origin 8.0.

\section{Docking Analysis of $\mathrm{GOxP}_{5}$ and $\beta$-D-Glucose}

Automatic homology modeling of $\mathrm{GOxP}_{5}$ was performed using the Phyre2 program ${ }^{2}$ (Kelley et al., 2015). The tertiary structure of $\mathrm{GOxP}_{5}$ was docked with its substrate $\beta$-D-glucose using AutoDock Tools 1.5.6. The most reasonable docking complex was chosen according to the guidelines mentioned in previous reports (Trott and Olson, 2010). PyMOL software (v1.7.2; Delano Scientific, United States) was used to visualize three-dimensional structures and prepare figures.

\section{Antibacterial Evaluation of $\mathrm{GOXP}_{\mathbf{5}}$}

The Oxford cup method (Wang et al., 2011) was used to determine the antibacterial effect of recombinant $\mathrm{GOxP}_{5}$ on five bacteria including Escherichia coli (ATCC 25922), Salmonella derby (ATCC 13076), Staphylococcus aureus (ATCC 6538), Vibrio parahaemolyticus (ATCC 17802), and Listeria monocytogenes (ATCC 19115). Each bacterium was cultivated and adjusted to $10^{7} \mathrm{CFU} / \mathrm{mL}$, spread on petri dishes of LB or TSB medium. Based on the study of Liu et al. (2020c), the Oxford cups were put on the culture medium, $150 \mu \mathrm{L}$ recombinant $\mathrm{GOxP}_{5}$ solution (with $2 \%$ glucose added) with enzyme activity of 1 and $2 \mathrm{U} / \mathrm{mL}$, respectively, were added to the Oxford cups. Sterile normal saline solution was used as a control. Finally, the strains were incubated at $37 \pm 1^{\circ} \mathrm{C}$ for $24 \mathrm{~h}$.

Furthermore, the antibacterial activity of $\mathrm{GOxP}_{5}$ (with $2 \%$ glucose added) was evaluated by measuring the minimum inhibitory concentration (MIC) and the minimum bactericidal concentration $(\mathrm{MBC})$ by the broth dilution method (Başyiğit et al., 2020). The effect of the $\mathrm{GOxP}_{5}$ on growth curves of $L$. monocytogenes and $V$. parahemolyticus were studied by adding $\mathrm{GOxP}_{5}$ with different concentrations of $4 \times \mathrm{MIC}, 2 \times \mathrm{MIC}$, $1 \times \mathrm{MIC}, 1 / 2 \times \mathrm{MIC}, 1 / 4 \times \mathrm{MIC}$, and sterile normal saline solution was used as control.

\section{SEM Observation}

The L. monocytogenes and $V$. parahemolyticus were cultured to $10^{7} \mathrm{CFU} / \mathrm{mL}$, incubated with MIC concentration of $\mathrm{GOxP}_{5}$ (with $2 \%$ glucose added) for $2 \mathrm{~h}$. The samples suspended in PBS were then fixed in $2.5 \%$ glutaraldehyde solution and placed at $4^{\circ} \mathrm{C}$. The fixed samples were observed by Scanning Electron Microscopy (SEM) with $20 \mathrm{kV}$ of acceleration voltage after corresponding processing (Asad et al., 2020).

\section{FISH PRESERVATION EXPERIMENT}

\section{Fishes Collection and Treatment}

Five live grass carps weighing approximately $1 \mathrm{~kg}$ each were purchased from the Tuandao aquatic market in Qingdao, China,

\footnotetext{
${ }^{2}$ http://www.sbg.bio.ic.ac.uk/phyre2/html/page.cgi?id=index
} 
and immediately transported alive in water to the laboratory within $3 \mathrm{~h}$. In the laboratory, we first percussive stunning, then fish were killed by sectioning the spinal cord at the base of the head immediately, to meets the requirements of ethical standards (López-Luna et al., 2013). All fish experiments has been carried out in accordance with European Food Safety Authority (2009) and EU Directive 2010/63/EU. The grass carps were stunned, scaled, gutted, decapitated, deboned, and peeled manually before immediately cleaning and washing with saline water. Each fish was divided into 10 pieces, each piece weighing between 30 and $40 \mathrm{~g}$. The $\mathrm{GOxP}_{5}(12.5 \mathrm{U} / \mathrm{mL})$ was diluted with sterile water to $1 \mathrm{U} / \mathrm{mL}$ according to Field et al. (1986) and Dondero et al. (1993). Then, the samples were randomly assigned to four treatments: the filets were drenched in 1.25\% SBS (sodium bisulfite), $0.5 \% \mathrm{Vc}$ (Vitamin C, Ascorbic Acid), or $1 \mathrm{U} / \mathrm{mL} \mathrm{GOxP}_{5}$ for $10 \mathrm{~min}$. Control samples were immersed in sterile water, removed and drained for $30 \mathrm{~min}$ after dipping. Each filet was packaged in polyethylene (PE) packaging pouches, sealed, and stored at $4^{\circ} \mathrm{C}$. All operations were performed on a UV-cleaned bench. Experiments were performed in triplicate for the sensory analysis, microbiological analysis [total bacterial count (TBC)], and physicochemical analysis [total volatile basic nitrogen (TVB$\mathrm{N}$ ) and $\mathrm{pH}$ ] of the grass carp filets; these experiments were conducted every second day at $4^{\circ} \mathrm{C}$ for samples stored over a 10 days period.

\section{Sensory Analyses}

Sensory analyses were performed using the method recommended by Ojagh et al. (2010) with some modifications; these analyses were performed by six rigorously trained laboratory panelists, and culculate of overall sensory score based on the Supplementary Table 2. Four parameters (texture, odor, color, and elasticity) were used to evaluate fish filet quality on a score from 1 to 10 , with 10 performing the best in terms of freshness and the score decreasing as the quality of the filets gradually decreased. Total sensory score result of 9 represents absolutely fresh, 7 represents acceptable, and 5 represents unacceptable.

\section{Microbiological Analysis}

The total bacterial count (TBC) was determined from plate count agar. Each weighed fish filet sample $(5 \mathrm{~g})$ was added to $45 \mathrm{~mL}$ sterile physiological saline water $(0.85 \%)$ and homogenized for 1 min; this was serially diluted with the same volume of normal saline water. Appropriate dilutions $(1 \mathrm{~mL})$ were poured into a petri dish and mixed with plate count agar medium (incubated at $30 \pm 1^{\circ} \mathrm{C}$ for $72 \mathrm{~h}$ ).

\section{Physicochemical Analysis}

Determination of total volatile basic nitrogen (TVB-N, mg/100 g sample) values was based on the current Chinese food safety standard method (GB 5009.228-2016) via a micro-diffusion method. A $10 \mathrm{~g}$ minced fish sample was dispersed in $50 \mathrm{~mL}$ of distilled water and filtered after $30 \mathrm{~min}$ of immersion. Then, $1 \mathrm{~mL}$ filtrate was mixed with $1 \mathrm{~mL}$ saturated $\mathrm{K}_{2} \mathrm{CO}_{3}$ in a diffusion dish. Additionally, $1 \mathrm{~mL}$ distilled water was used instead of the filtrate as a control. After $2 \mathrm{~h}$ in an incubator at $37 \pm 1^{\circ} \mathrm{C}$, the distillate was collected into the center of a diffusion dish containing $1 \mathrm{~mL}$ of $25 \mathrm{~g} / \mathrm{L}$ boric acid and a mixed indicator. The distillate was titrated to calculate the result. A $10 \mathrm{~g}$ fish sample was ground using a JR-22 experimental meat grinder (Zhucheng HSBC Food Machinery Co., Ltd., Shandong, China) and determined by a digital $\mathrm{pH}$ meter (Horiba, LAQUAtwin-pH-22, Japan).

\section{Data Analysis}

All analyses were carried out in triplicate. The data were statistically analyzed using Origin 8.0 procedures, and the least significant difference (LSD) procedure was used to test significance using a significance threshold of $p<0.05$.

\section{RESULTS}

\section{Gene Cloning and Sequence Analysis}

The proGOxP 5 precursor gene consists of $1,818 \mathrm{bp}$, and the first 16 amino acids were identified using Signal 4.0 server prediction as a signal peptide. No introns were identified in the sequence. The mature protein is 590 amino acids long, and it has a calculated molecular weight $(\mathrm{Mw})$ of $63.86 \mathrm{kDa}$; the Isoelectric point $(\mathrm{pI})$ was $\mathrm{pH} 5.05$. $\mathrm{GOxP}_{5}$ was most similar to Penicillium subrubescens CBS 132785 (GenBank accession No.: OKO89536.1) based on the amino acid sequence in GenBank, exhibiting $83.78 \%$ identity. The two active sites His540 and His583 perform the roles of proton donor and proton acceptor, respectively (Supplementary Figure 1).

\section{High-Level Expression in P. pastoris X33 and High-Cell-Density Fermentation}

The optimized $\mathrm{GOxP}_{5}$ and proGOxP $\mathrm{P}_{5}$ genes (with the signal peptide coding sequences) were introduced into the expression vector $\mathrm{pPICZ} \alpha$ A and independently transformed into $P$. pastoris X33-competent cells. The $P$. pastoris recombinant strain $(\mathrm{X} 33 / \mathrm{GOx})$ with high enzyme activity was picked out via a three-round selection. The positive transformants showing the highest enzyme activity were screened from a total of 1,000 positive clones. After induction with methanol for $72 \mathrm{~h}$, the highest $\mathrm{GOxP}_{5}$ and proGOxP 5 activities reached 35 and $7 \mathrm{U} / \mathrm{mL}$, respectively. Cultures of the control strain X33/pPICZ $\alpha$ A did not exhibit GOx activity.

For gaining high yield of $\mathrm{GOxP}_{5}$, the recombinant $P$. pastoris showing highest enzyme production capacity in shake flasks (35 U/mL) was further enlarged in a $20 \mathrm{~L}$ fermentor. As shown in Figure 1A, the enzyme yield underwent a continuous accumulation process in the former $145 \mathrm{~h}$, and reached 458.6 $\mathrm{U} / \mathrm{mL}$ (crude protein, $3.34 \mathrm{~g} / \mathrm{L}$ ) at this time point, which was about 12 times higher than the maximal enzymatic activity yield in shake flask.

\section{Purification of $\mathrm{GOXP}_{5}$ and proGOxP}

GOx was easily purified from $P$. pastoris culture supernatants using Ni-affinity chromatography owing to the correct exposure 


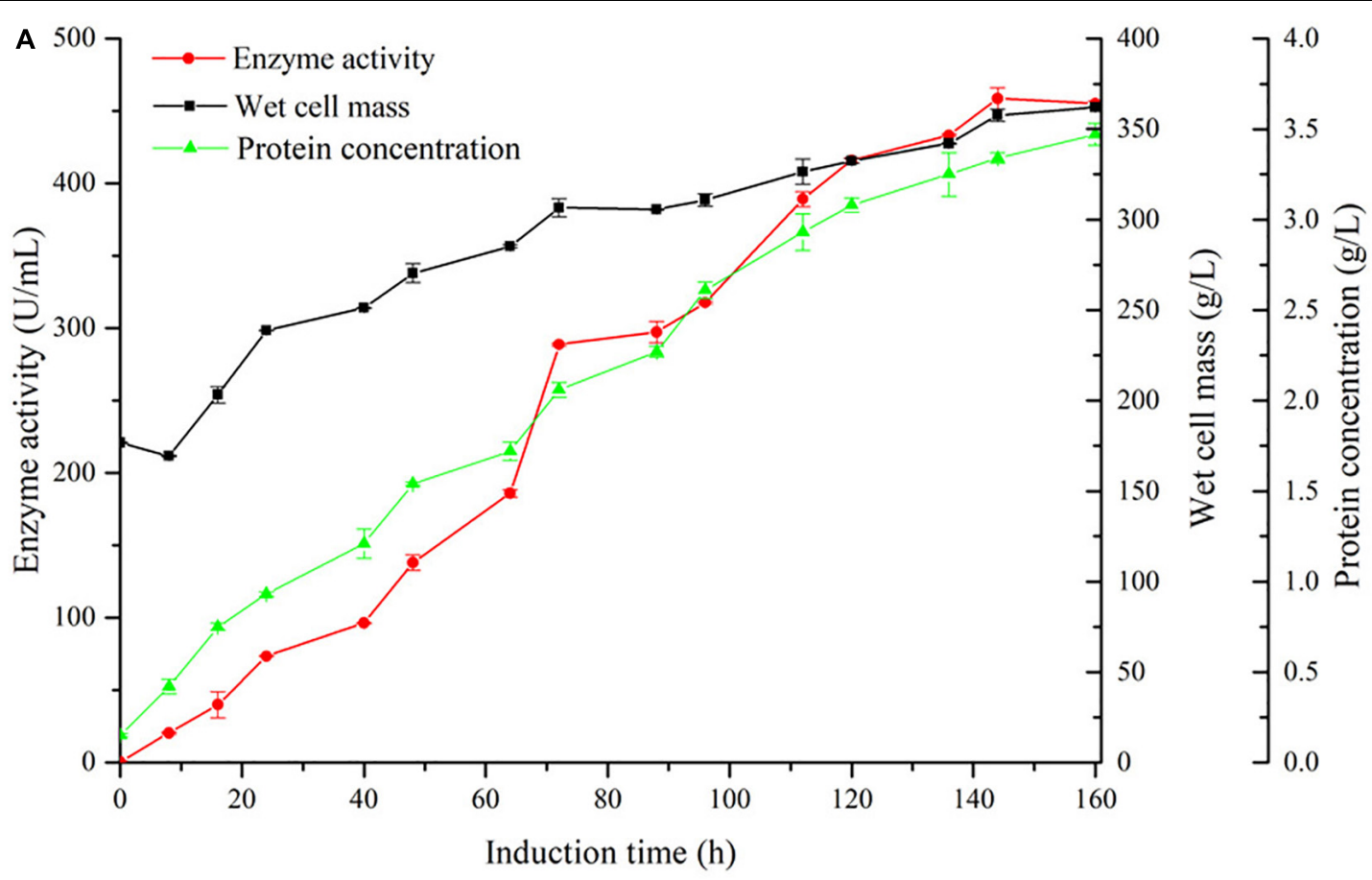

B

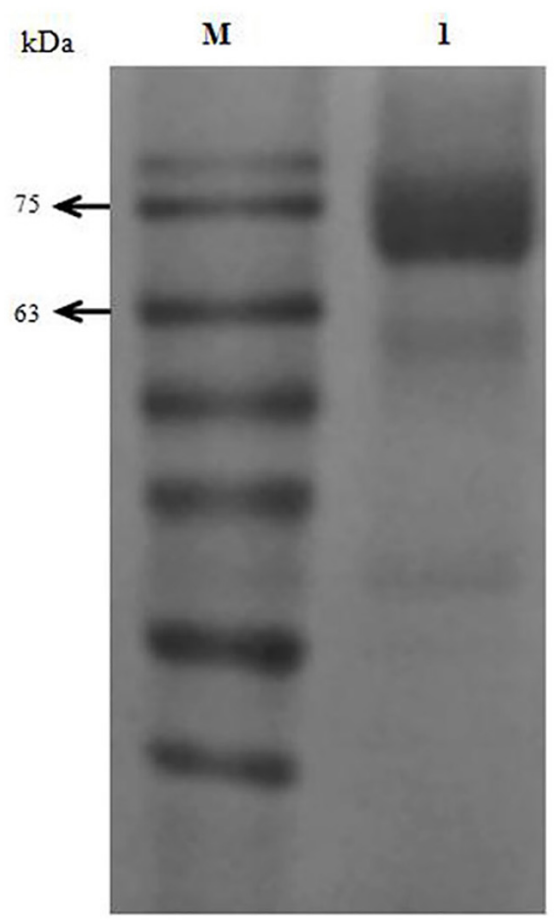

C

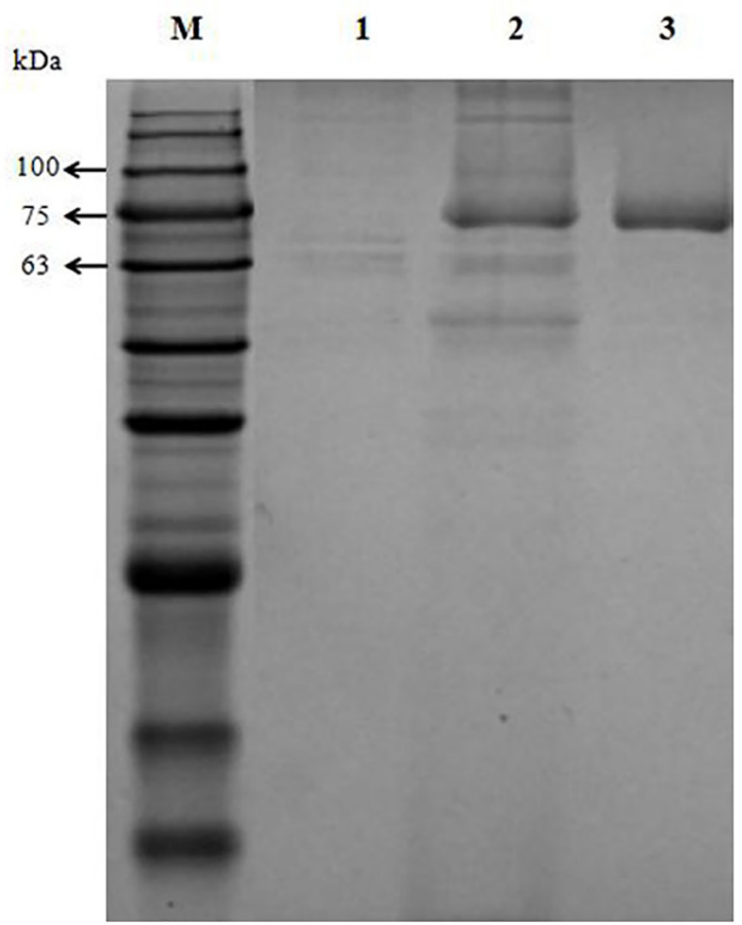

FIGURE 1 | Time-course of GOXP 5 in 20 L fermenter (A) and SDS-PAGE analysis (B) of recombinant glucose oxidase. The enzyme activity (•), wet cell mass ( $\mathbf{\square})$, protein concentration $(\mathbf{\Lambda})$ were measured during high-cell-density fermentation. Line M, protein marker; line 1, purified GOxP $\mathrm{P}_{5}$ fermentation supernatant withdrawn at $120 \mathrm{~h}$ after methanol induction. The supernatant samples after $96 \mathrm{~h}$ fermentation in shake flask of control strain pPICZ $\alpha$ AX33(line 1), the crude cell extract (line 2), and purified GOxP5 (line 3) were displayed by SDS-PAGE (C). 
of the $6 \mathrm{x}$ His tag to the recombinant enzyme. After fivefold purification with a final yield of 50\%, SDS-PAGE of the purified recombinant $\mathrm{GOxP}_{5}$ indicated that the $\mathrm{Mw}$ of a single band was around $70 \mathrm{kDa}$ (Figures $\mathbf{1 B}, \mathbf{C}$ ).

\section{Properties of Recombinant $\mathrm{GOXP}_{5}$ and proGOxP 5}

The optimal temperature and thermal stability of recombinant GOx are shown in Figures $\mathbf{2 A}, \mathbf{B}$. $\mathrm{GOxP}_{5}$ and proGOxP 5 had the same optimal temperature at $35^{\circ} \mathrm{C}$. $\mathrm{GOxP}_{5}$ could retain more than $80 \%$ of the highest activity at $10-45^{\circ} \mathrm{C}$, and even at $4^{\circ} \mathrm{C}$, it maintained $72.6 \%$ of the highest enzyme activity. In contrast, proGOxP 5 retained $80 \%$ of its enzyme activity in only a narrow temperature range of $20-40^{\circ} \mathrm{C}$. Recombinant $\mathrm{GOxP}_{5}$ and $\mathrm{proGOxP}_{5}$ exhibited the same optimum activity at $\mathrm{pH} 5.5$ and could retain more than $50 \%$ activity over the $\mathrm{pH}$ range of 3.0-7.0 (Figures 2C,D). For $\mathrm{pH}$ stability, both enzymes retained more than $60 \%$ of the maximum activity from $\mathrm{pH} 2.0-5.0$ after incubating at $25^{\circ} \mathrm{C}$ for $2 \mathrm{~h}$, with $\mathrm{GOxP}_{5}$ remaining above $70 \%$. In addition, it could retain more than $50 \%$ of the original activity after a $2 \mathrm{~h}$ incubation, even at $\mathrm{pH}$ 6.0-7.0. Recombinant $\mathrm{GOxP}_{5}$ displayed better acidic and neutral stability.

Several ions and chemical reagents had similar activation or inhibitory effects on the enzyme activity of purified $\mathrm{GOxP}_{5}$ and proGOxP $\mathrm{P}_{5}$ as shown in Supplementary Figure 2. Most additives, such as $\mathrm{K}^{+}, \mathrm{Na}^{+}, \mathrm{Mg}^{2+}, \mathrm{Zn}^{2+}, \mathrm{Fe}^{3+}$, SDS, and EDTA, could activate the recombinant enzymes to enhance enzyme activity. Further, $5 \mathrm{mM} \mathrm{Na}^{+}, \mathrm{Fe}^{3+}$, and SDS caused 10$15 \%$ enhancement. Result showed that test ions and reagents had little inhibitory effect on these two enzymes with the exception of $\mathrm{Fe}^{2+}, \mathrm{Ag}^{+}$, and $\mathrm{Cu}^{2+}$. Purified recombinant $\mathrm{GOxP}_{5}$ and proGOxP $\mathrm{P}_{5}$ displayed the maximum activity with D-glucose $(100 \%)$ as a substrate and exhibited high substrate specificity (Supplementary Table 1). They exhibited no activity with substrates such as D-fructose, D-raffinose, D-arabinose, D-mannitol, lactose, and sucrose. They exhibited low reactivity (1-20\%) to D-maltose, stachyose, D-galactose, D-mannose, D-sorbitol, and D-xylose. Therefore, glucose was used as the substrate to determine the kinetic parameters.

The $\mathrm{K}_{\mathrm{m}}$ values of $\mathrm{GOxP}_{5}$ and proGOxP$_{5}$ were 65.7 and $28 \mathrm{mM}$, respectively, which was similar to those of other previously reported fungal GOxs (Table 2). Though a higher $\mathrm{K}_{\mathrm{m}}$ value contributed to a lower affinity for $\beta$-D-glucose from this GOx, it was also related to substrate concentration (Guo et al., 2010). The $\mathrm{k}_{\text {cat }} / \mathrm{K}_{\mathrm{m}}$ of $\mathrm{GOxP}_{5}$ was $2086.758 \mathrm{~mol}^{-1} \cdot \mathrm{L} \cdot \mathrm{s}^{-1}$, which was about twice that of proGOxP $\mathrm{P}_{5}$, and it better reflected the excellent catalytic efficiency of $\mathrm{GOxP}_{5}$. Interestingly, as a whole, the activity and stability of $\mathrm{GOxP}_{5}$ was better than that of proGOxP $\mathrm{P}_{5}$, which, according to Han et al. (2018) could be due to the signal peptide.

\section{Docking Analysis of $\mathrm{GOxP}_{5}$ and $\beta$-D-Glucose}

As depicted in the docking complex of $\mathrm{GOxP}_{5}$ and $\beta-\mathrm{D}$ glucose (Figure 3A), the glucose could properly dock into the catalytic cavity of the homologous $\mathrm{GOxP}_{5}$ model. Two catalytic amino acid sites, His 540 and His 583 , located in two adjacent random coils, function as the proton donor and proton acceptor, respectively. The glucose could be fastened into the $\mathrm{GOxP}_{5}$ catalytic domain by forming non-covalent interactions with surrounding residues. As indicated in Figure 3B, $\beta$ D-glucose could form four conventional hydrogen bonds with $\operatorname{Ser}_{133}, \mathrm{Arg}_{447}, \mathrm{Arg}_{536}$, and $\mathrm{Asn}_{538}$, and two carbon hydrogen bonds with $\mathrm{His}_{540}$ and His ${ }_{583}$. Moreover, Van der Waals interactions surrounding the binding sites of $\beta-\mathrm{D}$ glucose also greatly contribute to its stable binding in the correct position.

\section{Antibacterial Evaluation of $\mathrm{GOxP}_{\mathbf{5}}$}

Using diffusion assays [zone of inhibition (ZOI) experiments], the recombinant $\mathrm{GOxP}_{5}(2 \mathrm{U} / \mathrm{mL})$ induced $18.12,12.2$, and $19.1 \mathrm{~mm}$ ZOI diameters against of S. aureus, L. monocytogenes, and $V$. parahaemolyticus, respectively (Figure 4). While $V$. parahaemolyticus is Gram-negative strain, its growth was significantly inhibited as judged from MIC values $(0.48 \mathrm{U} / \mathrm{mL})$. At the same time, $\mathrm{MIC}$ value of $\mathrm{GOxP}_{5}$ were best against Gram-negative bacteria ( $S$. derby and E. coli) at $0.96 \mathrm{U} / \mathrm{mL}$. However, its seems that the 2 Grampositive strains (L. monocytogenes and $S$. aureus) which were tested had a lower MIC than the 3 Gram-negative ones (Roy, 2009). Furthermore, the MIC value of $\mathrm{GOxP}_{5}$ for S. aureus and L. monocytogenes was $0.24 \mathrm{U} / \mathrm{mL}$; of note, against $S$. derby and E. coli the MIC was up to $0.96 \mathrm{U} / \mathrm{mL}$ (Table 3). Interestingly, the determined $\mathrm{MBC}$ was found to be twice the MIC.

Since L. monocytogenes and $V$. parahemolyticus are common pathogenic bacteria in aquatic products, the effect of $\mathrm{GOXP}_{5}$ on their antibacterial growth curves was further determined. Importantly, the growth curves reflected the inhibitory effect of different $\mathrm{GOxP}_{5}$ concentrations on L. monocytogenes and $V$. parahemolyticus (Figures $\mathbf{5 A}, \mathbf{B}$ ), When a $\mathrm{GOxP}_{5}$ concentration lower than the MIC was used, the exponential phase was shorter than that in control bacterial cultures. On the other hand, when the concentration exceeded the MIC, the bacterial growth was completely inhibited. Furthermore, SEM images showed that $\mathrm{GOXP}_{5}$ (MIC concentration) caused different effects on L. monocytogenes and $V$. parahemolyticus. After $2 \mathrm{~h}$ of inoculation with $\mathrm{GOxP}_{5}$, the morphology of L. monocytogenes was destroyed, the cell membrane shrank and ruptured, and the cells stacked and adhered (Figure 6B). In comparison, the $V$. parahemolyticus cell membrane remained smooth, while the cells stacked and became shorter (Figure 6D).

\section{EFFECT of $\mathrm{GOXP}_{5}$ ON FISH PRESERVATION}

\section{Changes in Sensory Quality}

In the grass carp preservation experiment, overall sensory quality scores for samples stored at $4^{\circ} \mathrm{C}$ are presented in Figure 7A, based on color, taste, odor, elasticity, and texture. Initially, the filets 


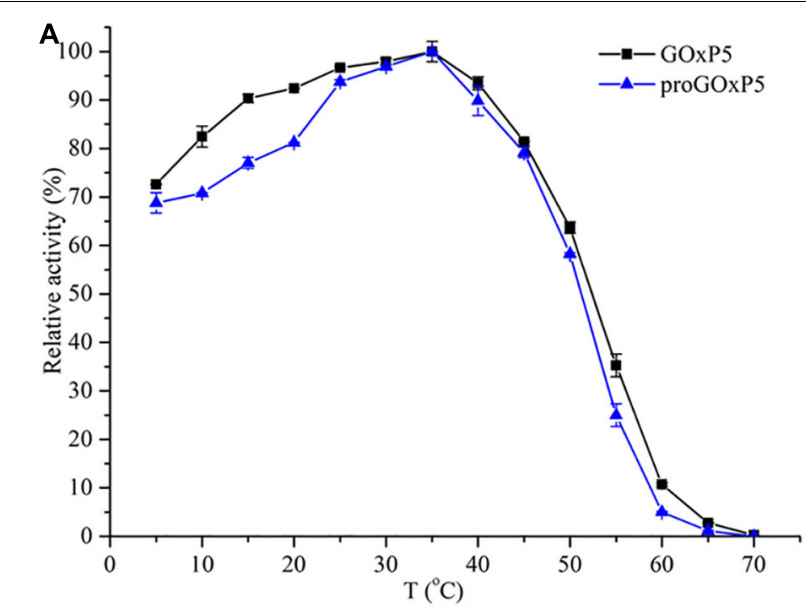

C

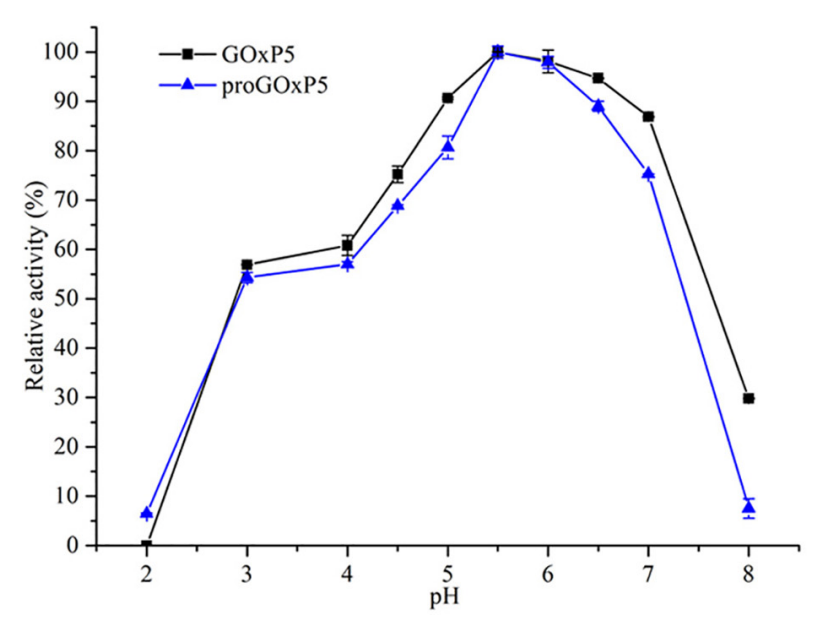

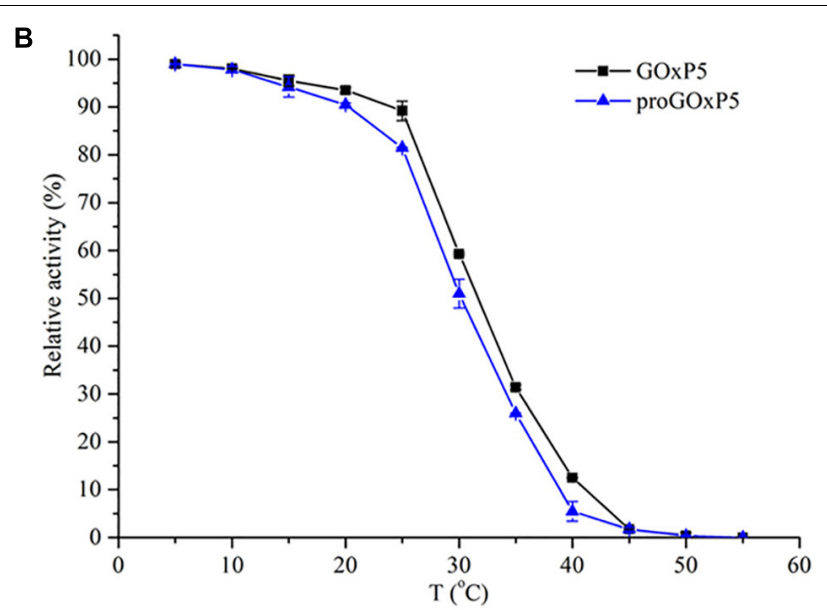

D

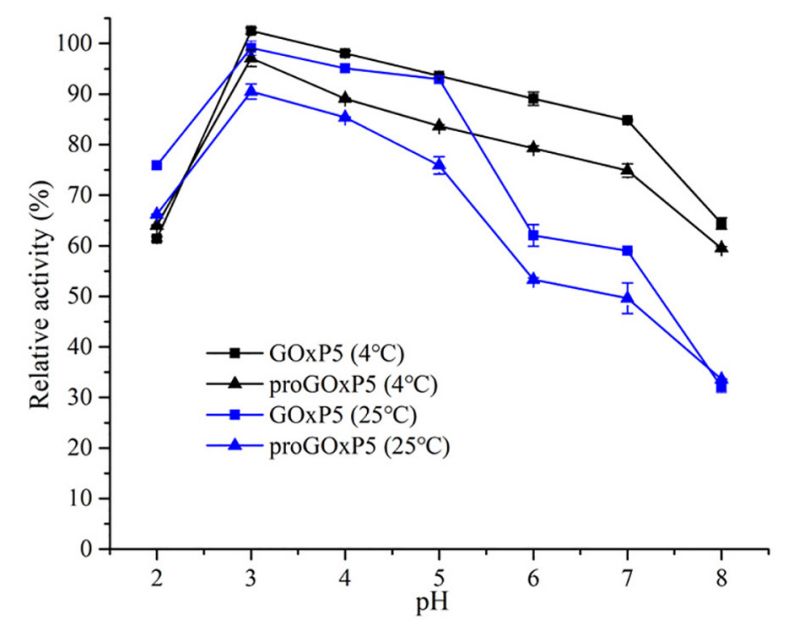

FIGURE 2 | Determination of optimum temperature (A), thermostability (B), optimum pH (C), and pH stability (D) of purified GOxP5 and proGOxP5. The optimal temperature was determined at temperatures ranging from 4 to $70^{\circ} \mathrm{C}$ in $50 \mathrm{mM}$ sodium phosphate sodium citrate buffer ( $\mathrm{pH}$ 6.0) (A). For the analysis of thermostability, the purified enzymes were incubated in $50 \mathrm{mM}$ sodium phosphate (pH6.0) for 5 min at $40-60^{\circ} \mathrm{C}$ (B). The initial enzyme (without incubation) activity of each enzyme was defined as 100\%. All the experiments were done in triplicates and the error bars indicate standard deviations. Optimal pH was measured in different buffers such as pH 2.0-3.0 (0.05 M glycine-HCl), pH 4.0-6.0 (0.05 M NaAc-HAc), and pH 7.0-8.0 (0.05 M Tris- $\mathrm{HCl})$ (C). For pH stability analysis, the enzymes were incubated with the above buffers for 120 min at 4 and $25^{\circ} \mathrm{C}$ (D).

were fresh, their sensory scores exhibited a significant decline from an initial value of 9 . The most obvious decline occurred in the CK group, which showed the SBS, Vc, and $\mathrm{GOXP}_{5}$ treatment groups were significantly better than the $\mathrm{CK}$ group. On the fourth day, the sensory score of the CK group was 5.5, which was lower than the acceptable value. However, the SBS and Vc scores reached an unacceptable level on the eighth (4.8) and tenth (4.7) days, respectively. Additionally, the $\mathrm{GOxP}_{5}$ treatment group scored 5 on the tenth day, which was still acceptable at the end of storage.

\section{Changes in Microbiological Quality}

The initial TBC of all samples was near (3.29 \pm 0.1$) \log \mathrm{CFU} / \mathrm{g}$ (Figure 7B). However, as the storage time of the fish filets in the four treatment groups increased, the TBC showed a distinctly different upward trend. On second day of storage, the TBC in the CK sample increased rapidly and reached $(4.81 \pm 0.09) \log$ $\mathrm{CFU} / \mathrm{g}$. However, SS, Vc, and GOx only reached 4.04, 4.5, and $3.65 \log \mathrm{CFU} / \mathrm{g}$, respectively. After 4.46 days of storage, the TBC for the CK group reached the upper acceptable value for freshwater species by ICMSF (1986), whereas the $\mathrm{GOxP}_{5}$ samples were within the acceptable range until 8.59 days. $\mathrm{SBS}$ and $\mathrm{GOxP}_{5}$ samples had 6.88 and $6.58 \log \mathrm{CFU} / \mathrm{g}$, respectively, at $4^{\circ} \mathrm{C}$ for $\mathrm{TBC}$ on the tenth day of storage but CK reached $8.04 \log \mathrm{CFU} / \mathrm{g}$.

\section{Changes in Physicochemical Quality}

TVB-N is mainly composed of volatile alkaline nitrogencontaining compounds such as ammonia and amines, which are formed as a result of the degradation of protein and non-protein nitrogenous compounds by microorganisms and enzymes. All 
TABLE 2 | Kinetic parameters of $\mathrm{GOXP}_{5}$ and proGOxP 5 .

\begin{tabular}{|c|c|c|c|c|c|}
\hline Sample & Specific activity $\left(\mathrm{U} \cdot \mathrm{mg}^{-1}\right)$ & $K_{m}\left(\mathrm{~mol} \cdot \mathrm{L}^{-1}\right)$ & $\mathrm{V}_{\max }\left(\mu \mathrm{mol} \cdot \mathrm{min}^{-1} \cdot \mathrm{mg}^{-1}\right)$ & $k_{\text {cat }}\left(s^{-1}\right)$ & $\mathrm{k}_{\mathrm{cat}} / \mathrm{K}_{\mathrm{m}}\left(\mathrm{mol}^{-1} \cdot \mathrm{L} \cdot \mathrm{s}^{-1}\right)$ \\
\hline proGOxP 5 & 34.19 & 0.0280 & 29.114 & 31.714 & 1132.642 \\
\hline $\mathrm{GO} \mathrm{P}_{5}$ & 149.05 & 0.0657 & 125.866 & 137.1 & 2086.758 \\
\hline
\end{tabular}

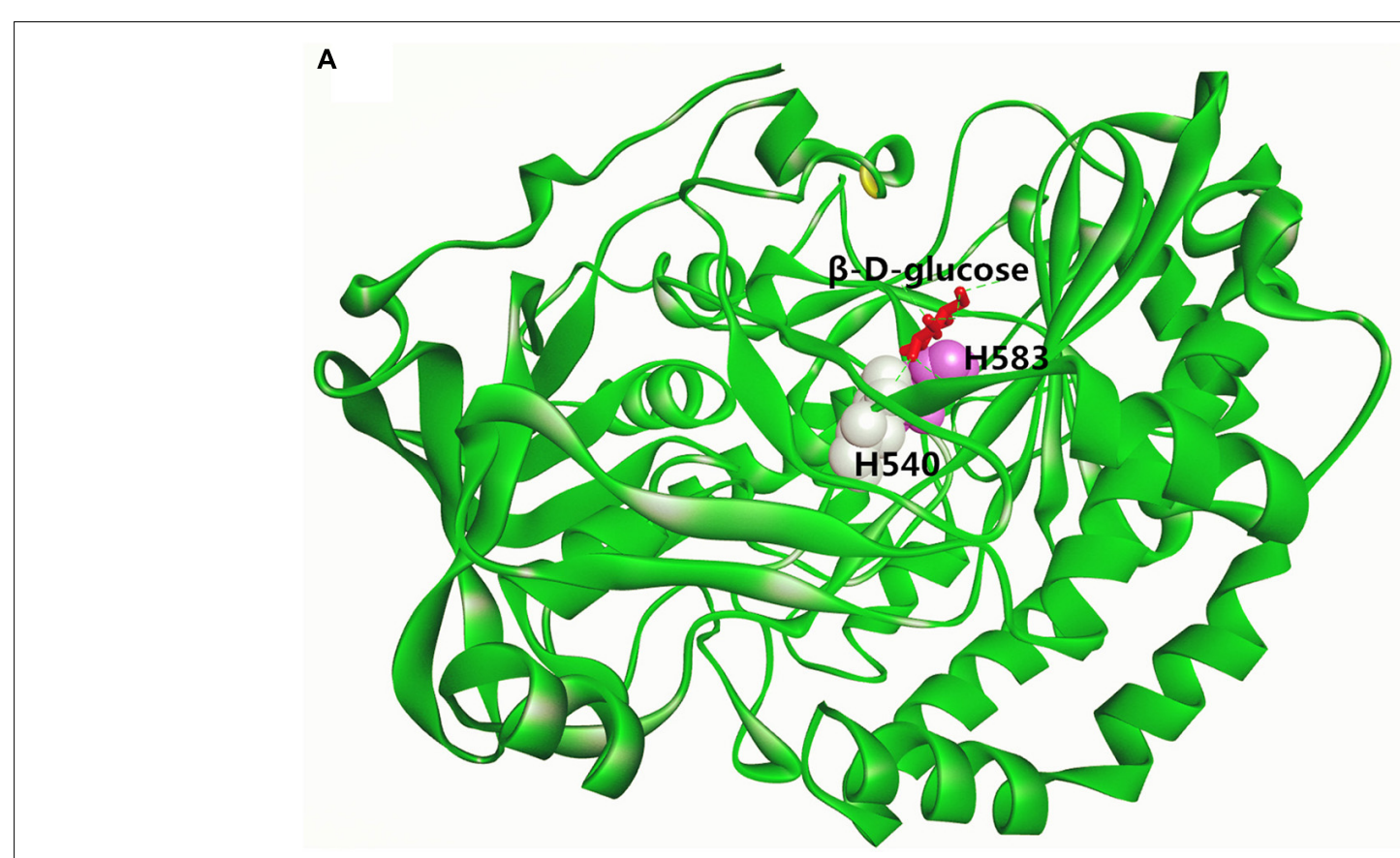

B

HIS
540

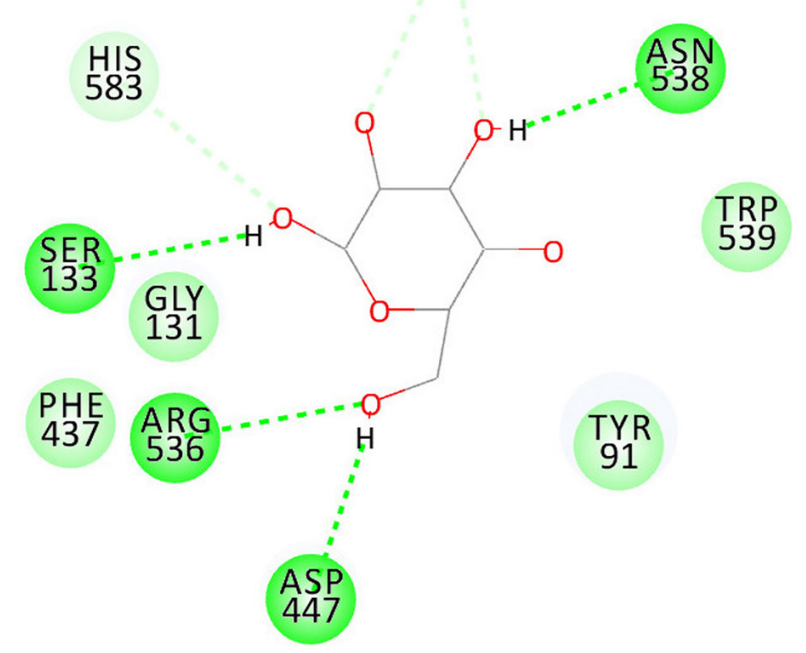

\section{Interactions}

van der Waals

Carbon Hydrogen Bond

Conventional Hydrogen Bond

FIGURE 3 | Overall structure of GOxP5 in complex with $\beta$-D-glucose (A). Two-dimensional diagrams of non-covalent interactions of $\beta$-D-glucose/GOxP5 docking complex (B). 


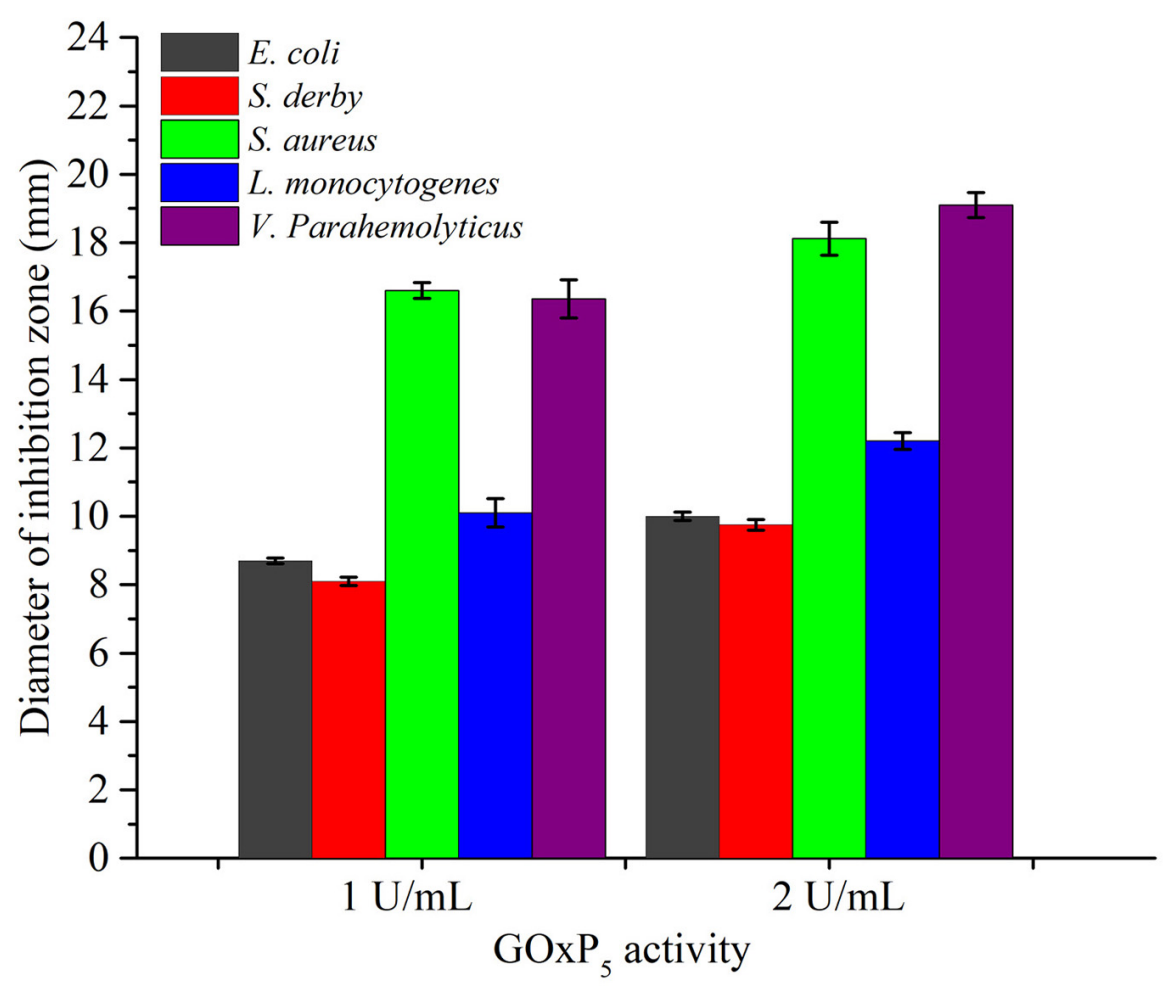

FIGURE 4 | The average diameter of inhibition zones of GOxP5 against five bacterial strains (E. coli, S. derby, S. aureus, V. parahemolyticus, L. monocytogenes).

TABLE 3 | MIC (U/mL) and MBC $(\mathrm{U} / \mathrm{mL})$ data of $\mathrm{GOXP} 5$.

\begin{tabular}{lccccc}
\hline Bacteria & E. coli & S. derby & S. aureus & L. monocytogenes & V. Parahemolyticus \\
\hline MIC & 0.96 & 0.96 & 0.24 & 0.24 & 0.48 \\
MBC & 1.20 & 1.20 & 0.48 & 0.48 & 0.96
\end{tabular}

groups showed increased TVB-N values as the storage time increased (Figure 7C); initially, the TVB-N of the fresh samples was $5.25 \mathrm{mg} / 100 \mathrm{~g}$. On the sixth day, the TVB-N value in the control group reached $25.2 \pm 1.13 \mathrm{mg} / 100 \mathrm{~g}$, which exceeded the limit of the secondary freshness. Until 10 days, the $\mathrm{GOxP}_{5}$ treatment was lower than the commercially acceptable limit of $30 \mathrm{mg} / 100 \mathrm{~g}$ (Ocaño-Higuera et al., 2011), whereas the control reached nearly $35.85 \pm 0.45 \mathrm{mg} / 100 \mathrm{~g}$.

Changes in the sample $\mathrm{pH}$ values during storage are presented in Figure 7D. The same trend in the $\mathrm{pH}$ with storage time was observed in all grass carp filets. The $\mathrm{pH}$ of all samples decreased in the first 2 days of the storage period. Then, the $\mathrm{pH}$ of the $\mathrm{CK}$, SBS, Vc, and $\mathrm{GOxP}_{5}$ groups increased from the initial 6.53-7.03, $6.86,6.89$, and 6.84 , respectively, at the end of the 10 days storage period. $\mathrm{GOxP}_{5}$ was most effective in delaying the $\mathrm{pH}$ increase compared to the SBS and Vc groups.

\section{DISCUSSION}

As a biopreservative, GOx has great application value in food preservation. However, cold active was a key limitation for GOx in fish preservative applications, and few reports have used new GOx with excellent enzyme activity to extend aquatic product shelf life. In our study, a new cold-active GOx was isolated and successfully expressed in $P$. pastoris, and the biochemical and antimicrobial characteristics of recombinant enzymes were comprehensively analyzed, which proved it has significant effects on the preservation of grass carp.

Zeocine-based liquid PTVA method for selecting high copy number clones has been verified an efficient way for constructing high growth rate and high protein yield stains (Aw and Polizzi, 2016). This result was in accordance with previous report that high-cell-density fermentation of $P$. pastoris normally enlarged the enzyme yield by ten folds ( $\mathrm{Li}$ et al., 2007; Figure 1A). After that, the total enzyme yield and wet cell mass tended to decrease, and the methanol consumption rate apparently reduced, which implied the deadline of fermentation. The maximal enzymatic activity of $\mathrm{GOxP}_{5}$ in shake flask was much higher than many heterologously expressed enzymes in $P$. pastoris, such as GOx form $P$. variable $(0.33 \mathrm{U} / \mathrm{mL}), A$. niger (1.23 U/mL), and $A$. niger NRLL-3 (17.5 U/mL) (Kalisz et al., 1997; Yamaguchi et al., 2007; Kovačević et al., 2014). Although 


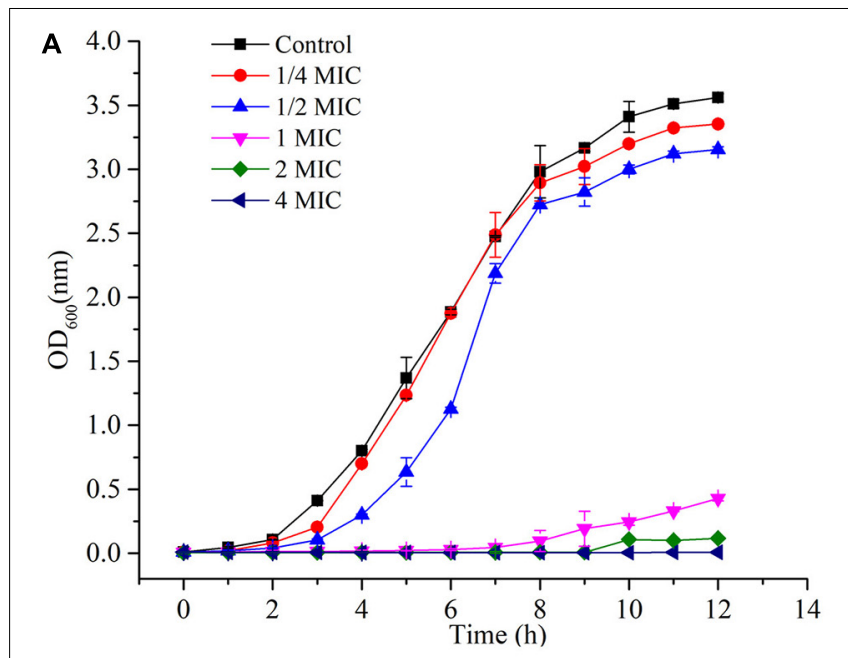

B

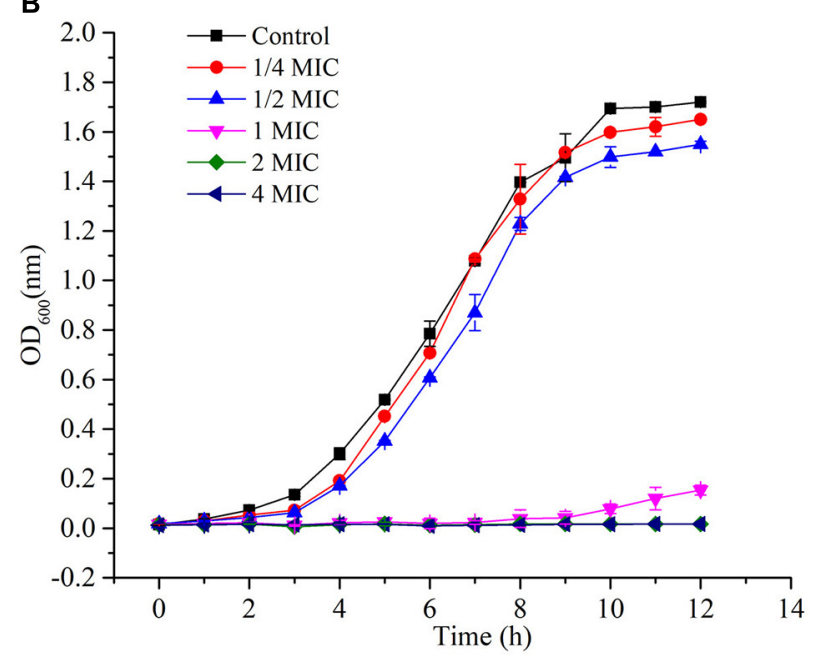

FIGURE 5 | Growth curves (A) L. monocytogenes and (B) V. parahemolyticus.

the highest expression level of $\mathrm{GOxP}_{5}$ in $P$. pastoris after high-cell-density fermentation was lower than that of GOD-m from Penicillium notatum (615 U/mL) (Gao et al., 2012), it was still of great value due to its excellent characteristics in food preservation area.

The optimum reported temperature range for most GOxs was from 25 to $60^{\circ} \mathrm{C}$ (Table 4). $\mathrm{GOxP}_{5}$, with an optimum temperature of $35^{\circ} \mathrm{C}$, in particular maintained $72.6 \%$ of the highest enzyme activity even at $4^{\circ} \mathrm{C}$. However, most reported fungal GOxs retained less than $70 \%$ of its maximum activity at $4^{\circ} \mathrm{C}$, which demonstrated $\mathrm{GOxP}_{5}$ had a higher activity at refrigeration temperature. $\mathrm{Tu}$ et al. (2019) showed that the activity of Aspergillus $\mathrm{GOx}$ at $20^{\circ} \mathrm{C}$ was approximately $75 \%$ of the highest activity. Although Sukhacheva et al. (2004) discovered that GOx from Penicillium could maintain about $80 \%$ at $20^{\circ} \mathrm{C}$, enzyme activity reduced rapidly with decreasing temperature. When the temperature dropped to $10-15^{\circ} \mathrm{C}$, its activity decreased significantly to $40 \%$ (Witt et al., 1998;
Courjean and Mano, 2011), which showed it is difficult to exert effective enzyme activity at $4^{\circ} \mathrm{C}$. However, a preservative that could effectively function at $4^{\circ} \mathrm{C}$ was required in the preservation of aquatic products especially fish. In addition, the $\mathrm{pH}$ value of most perishable foods such as meat, fish and shrimps was close to neutral, and $\mathrm{GOXP}_{5}$ could play a good role in this $\mathrm{pH}$ value range (Figure $2 \mathrm{C}$ ). When treated at $\mathrm{pH}=7$ and $4^{\circ} \mathrm{C}$ for $2 \mathrm{~h}$, the enzyme activity only lost $20 \%$, which further showed that it could work effectively under low temperature conditions (Figure 2D).

Their strong resistance to most metal ions and chemical reagents makes wide application potential for the food industry. The molecular weight of purified recombinant $\mathrm{GOxP}_{5}$ was approximately $6.14 \mathrm{kDa}$ larger than the theoretical Mw (Figure 1B). This demonstrated that N-glycosylation sites on the protein surface were glycosylated during posttranslational processing in P. pastoris (Kalisz et al., 1997). Research reports have shown that glycosylation may have an effect on the catalytic ability, but the influence was not obvious in this experiment (Crognale et al., 2006; Kohen et al., 1997). In addition, a comparative study indicated that the wild-type signal peptide apparently influenced the GOx expression level and biochemical properties. Specifically, recombinant $\operatorname{proGOxP}_{5}$ (containing native signal peptide) decreased the enzyme activity by nearly five times and only retained $62 \%$ of the maximum activity at $4^{\circ} \mathrm{C}$ (Figure 2). Consistent with the research of Chang et al. (2011), the N-terminal signal peptide had a negative effect on gene expression.

Since GOx can lead to the production of gluconic acid and $\mathrm{H}_{2} \mathrm{O}_{2}$, reducing the $\mathrm{pH}$, it indirectly possesses significant antimicrobial activity against different foodborne pathogens (Pluschkell et al., 1996; Bankar et al., 2009). Consistently with reported studies, GOx had a good antimicrobial effect on the common spoilage bacteria in food, and the antibacterial effect on L. monocytogenes and $V$. parahemolyticus was in different degree. As Gram-negative bacteria, $V$. parahaemolyticus was generally more resistant to antimicrobial biomolecules due to its lipopolysaccharide outer membrane (Roy, 2009). The result of SEM images confirmed that $\mathrm{GOxP}_{5}$ destroys the cell membrane integrity of specific bacteria (Figure 6), which further indicated its good antibacterial effect (Bankar et al., 2009).

In the experiment of fish preservation, sensory, microbiological analyses, and physicochemical changes of grass carp filets were evaluated during 10 days of storage at $4^{\circ} \mathrm{C}$ (Figure 7). Results showed $\mathrm{GOxP}_{5}$ had an excellent freshness preservation effect compared to the SBS and Vc. In particular, $\mathrm{GOxP}_{5}$ had a better effect on sensory quality. The ammonia, fishy, and putrid odors were light in the $\mathrm{GOxP}_{5}$ group, and these unpleasant odors were due to the spoilage of microorganisms that cause the accumulation of trimethylamine and biological amines (Field et al., 1986). The TBC of the CK group was significantly higher than the treated groups (SBS, Vc, and $\mathrm{GOxP}_{5}$ ). Although SBS had been considered as antimicrobial food additive and it was concluded that it decreases total bacteria (Omar, 1998), 


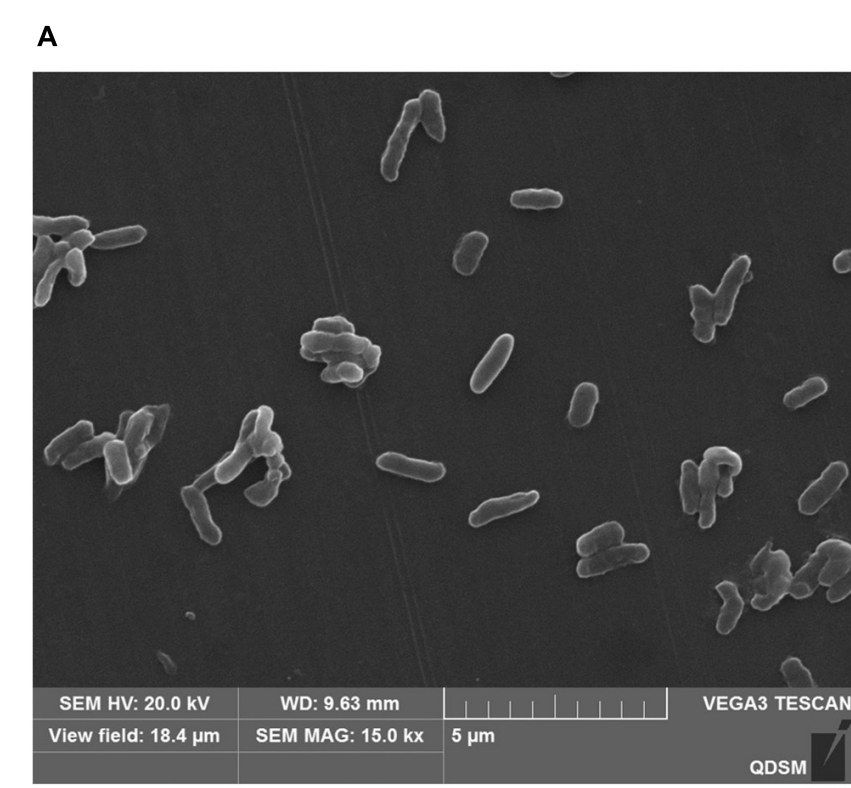

B

C

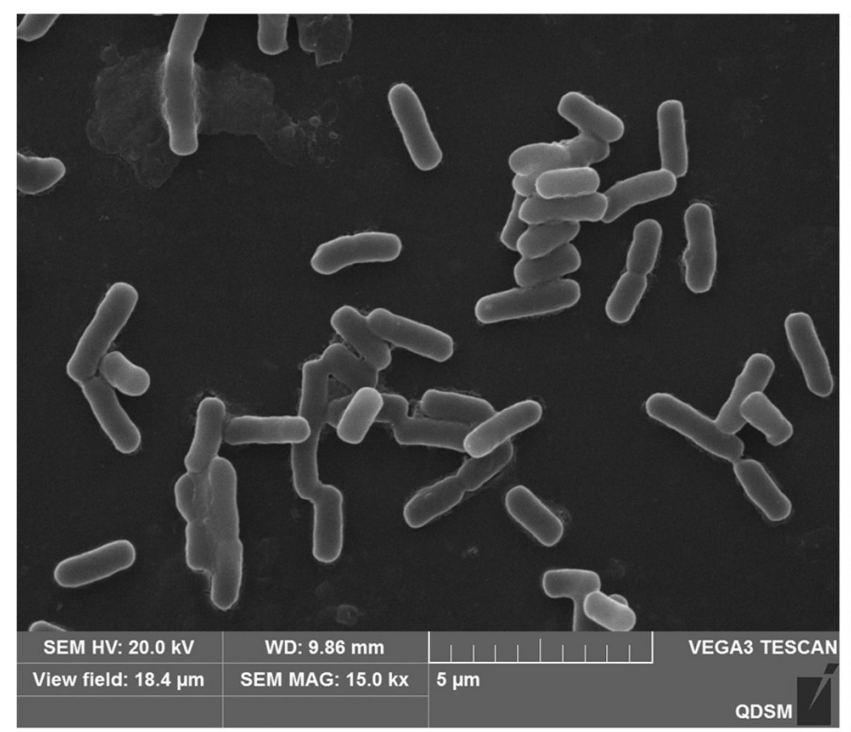

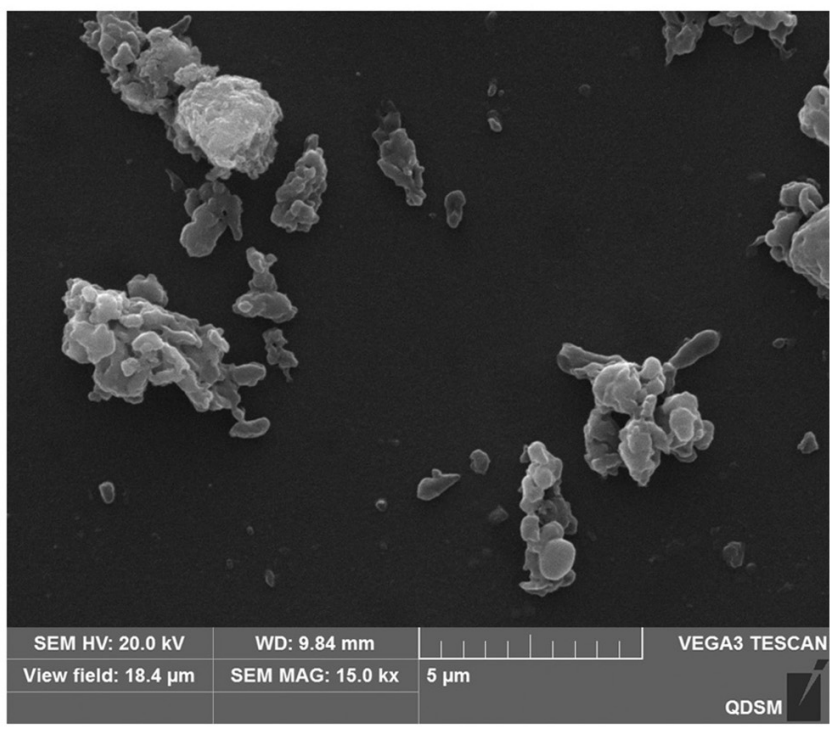

D

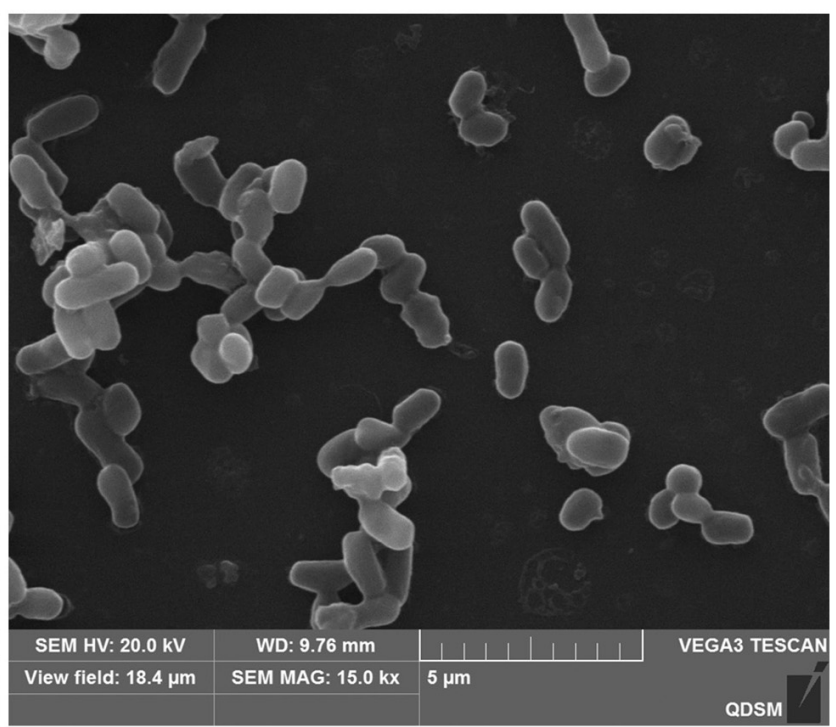

FIGURE 6 | Scanning electron microscopic (SEM) images showing effect of GOXP 5 on L. monocytogenes (B) and V. parahemolyticus (D). (A,C) represents the blank control.

it was still not as advantageous as $\mathrm{GOxP}_{5}$. The significant difference between $\mathrm{GOxP}_{5}$ and the other three treatments can be owing to the strong inhibitory effect of released $\mathrm{H}_{2} \mathrm{O}_{2}$. At the same conditions, the $\mathrm{GOxP}_{5}$ treatment group could be extended for 3 days based on the TVB$\mathrm{N}$ analyses. The results showed that $\mathrm{pH}$ values in all fish samples decreased initially before increasing. Researchers indicated that the initial $\mathrm{pH}$ decreases could be associated with lactic acid during anaerobic glycolysis and inorganic phosphate released by ATP degradation, and the subsequent $\mathrm{pH}$ increase might be attributed to amine and trimethylamine accumulation (Liu et al., 2013; Yu et al., 2017). Therefore, the shelf life of grass carp could be significantly extended after $\mathrm{GOxP}_{5}$ treatment.

Since $\mathrm{GOxP}_{5}$ had an excellent effect compared to traditional chemical preservatives mentioned before, it is promising for its application for the biopreservation of high added-value perishable foods such as fresh fish filets or seafood. Previous studies demonstrated that the application of composite biological preservatives (lysozyme, nisin, and others) in aquatic products could more effectively extend the shelf life than a single preservative. Morsy et al. (2018) provided a combination of nisin, lysozyme, and $\mathrm{ZnO}$ nanoparticles effectively inhibiting Escherichia coli, Bacillus cereus, and 


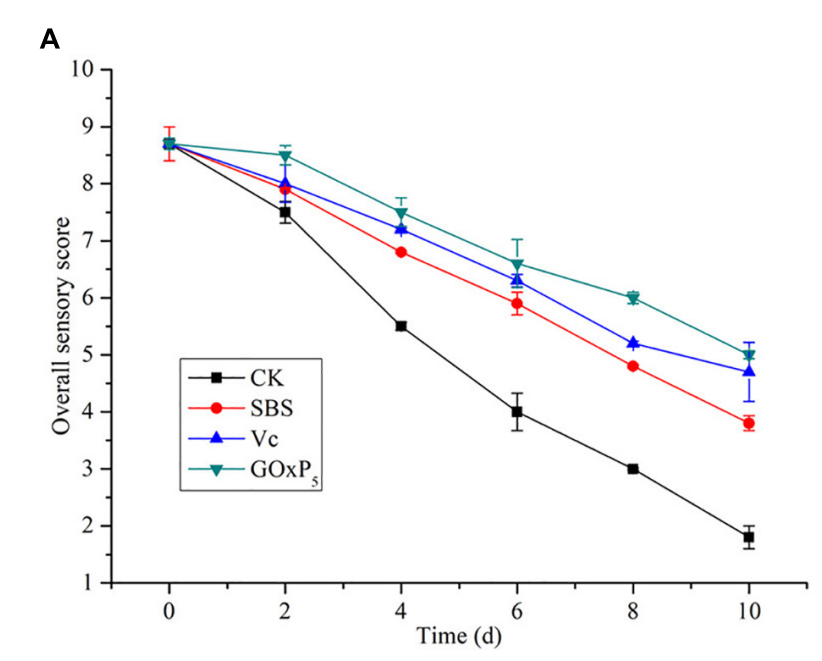

c

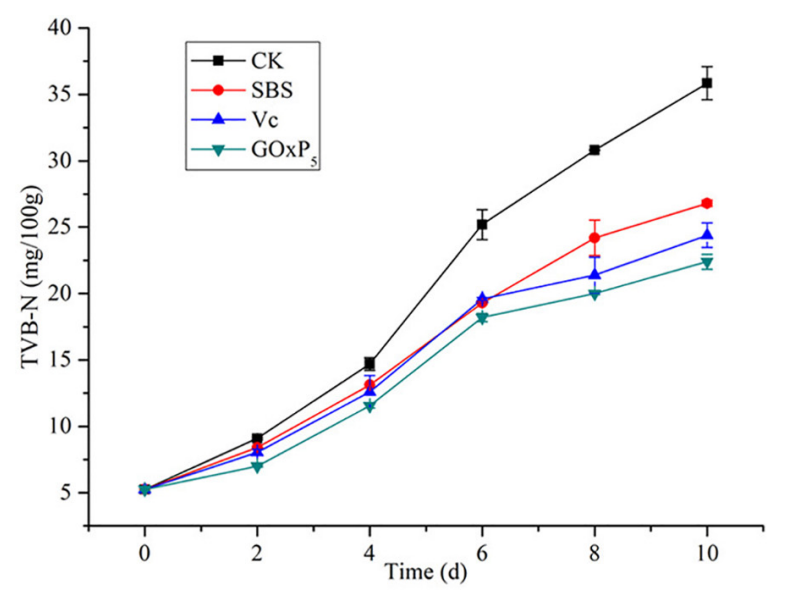

B

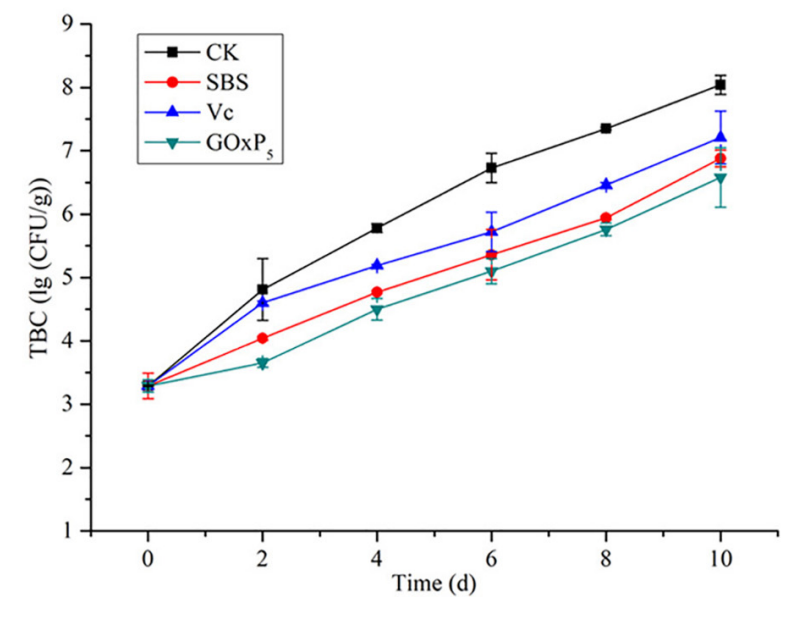

D

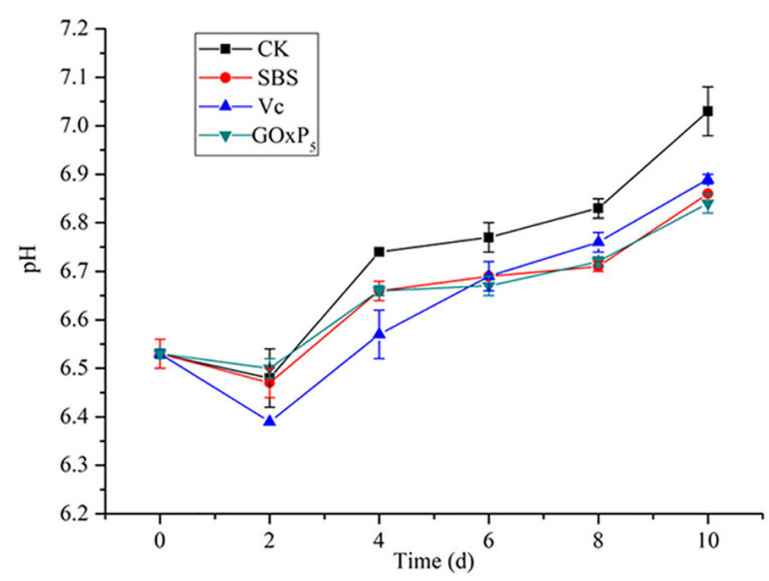

FIGURE 7 | Changes in sensory quality (A), total bacterial counts (B), TVB-N (C), and pH (D) values of grass carp filets with different treatments of preservatives during storage at $4^{\circ} \mathrm{C}$. The vertical bars represent the standard deviations $(n=2)$.

TABLE 4 | Comparison of the properties of $\mathrm{GOXP}_{5}$ with different fungal GOxs.

\begin{tabular}{|c|c|c|c|c|c|c|}
\hline GOx source & $\begin{array}{l}\text { Temperature } \\
\text { optimum }\left({ }^{\circ} \mathrm{C}\right)\end{array}$ & Cold adapted & pH optimum & $\mathrm{K}_{\mathrm{m}}(\mathrm{mM})$ & $\mathrm{k}_{\mathrm{cat}} / \mathrm{K}_{\mathrm{m}}\left(\mathrm{mM}^{-1} \cdot \mathrm{s}^{-1}\right)$ & References \\
\hline Penicillium sp. & 30 & $>72 \%$ activity at $5^{\circ} \mathrm{C}$ & 5.5 & 65.7 & 2.09 & This study \\
\hline Aspergillus tubingensis & 60 & $<40 \%$ activity at $30^{\circ} \mathrm{C}$ & 4.5 & 53.23 & 11.32 & Kriaa et al., 2015 \\
\hline Penicillium amagasakiense & 28 & $33.3 \%$ activity at $15^{\circ} \mathrm{C}$ & 7.0 & - & - & Witt et al., 1998 \\
\hline Penicillium amagasakiense & $40-50$ & $<40 \%$ activity at $10^{\circ} \mathrm{C}$ & $4.5-6.5$ & 6.2 & 323 & $\begin{array}{l}\text { Kalisz et al., 1997; } \\
\text { Courjean and } \\
\text { Mano, } 2011\end{array}$ \\
\hline Penicillium funiculosum 433 & 30 & About $80 \%$ activity at $20^{\circ} \mathrm{C}$ & $6.0-8.6$ & 3.3 & - & $\begin{array}{l}\text { Sukhacheva et al., } \\
2004\end{array}$ \\
\hline Penicillium variabile $\mathrm{P} 16$ & 45 & About $60 \%$ activity at $30^{\circ} \mathrm{C}$ & 6.0 & 15.25 & $5.58 \times 10^{4}$ & $\begin{array}{l}\text { Crognale et al., } \\
2006\end{array}$ \\
\hline
\end{tabular}

Listeria monocytogenes and increasing refrigerated beef safety. In addition, Ge et al. (2012) immobilized GOx in an electrospun nanofibrous membrane, which had obvious bacteriostatic activity against bacteria for food preservation.
Thus, the cold-active $\mathrm{GOxP}_{5}$ has great application value in grass carp preservation as a biopreservative in this study, the application scope could be further extended by combing with other preservatives. 


\section{DATA AVAILABILITY STATEMENT}

The datasets presented in this study can be found in online repositories. The names of the repository/repositories and accession number(s) can be found in the article/ Supplementary Material.

\section{AUTHOR CONTRIBUTIONS}

MY: investigation, data curation, writing-original draft preparation, and methodology. CN: methodology and writingreview. SY: visualization and formal analysis. QL: software and data curation. ZL: conceptualization and data curation. HM: writing-review, editing, supervision, funding acquisition, and

\section{REFERENCES}

Asad, M., Arshad, M. N., Oves, M., Khalid, M., Khan, S. A., Asiri, A. M., et al. (2020). N-Trifluoroacetylated pyrazolines: Synthesis, characterization and antimicrobial studies. Bioorg. Chem. 99:103842. doi: 10.1016/j.bioorg.2020. 103842

Aw, R., and Polizzi, K. M. (2016). Liquid PTVA: a faster and cheaper alternative for generating multi-copy clones in Pichia pastoris Microb. Cell Fact. 15, 1-11. doi: 10.1385/0-89603-421-6:1

Bankar, S. B., Bule, M. V., Singhal, R. S., and Ananthanarayan, L. (2009). Glucose oxidase - an overview. Biotechnol. Adv. 27, 489-501. doi: 10.1016/j.biotechadv. 2009.04.003

Başyiǧit, B., Sağlam, H., Kandemir, Ş, Karaaslan, A., and Karaaslan, M. (2020). Microencapsulation of sour cherry oil by spray drying: evaluation of physical morphology, thermal properties, storage stability, and antimicrobial activity. Powder Technology. 364, 654-663. doi: 10.1016/j.powtec.2020.02.035

Bradford, M. M. (1976). A rapid and sensitive method for the quantitation of microgram quantities of protein utilizing the principle of protein-dye binding. Anal. Biochem. 72, 248-254. doi: 10.1016/0003-2697(76)90527-3

Chang, S. W., Li, C. F., Lee, G. C., Yeh, T., and Shaw, J. F. (2011). Engineering the expression and biochemical characteristics of recombinant candida rugosa LIP2 lipase by removing the additional $\mathrm{n}$-terminal peptide and regional codon optimization. J. Agric. Food Chem. 59, 6710-6719. doi: 10.1021/jf200537w

Courjean, O., and Mano, N. (2011). Recombinant glucose oxidase from Penicillium amagasakiense for efficient bioelectrochemical applications in physiological conditions. J. Biotechnol. 151, 122-129. doi: 10.1016/j.jbiotec.2010.10.077

Crognale, S., Pulci, V., Brozzoli, V., Petruccioli, M., and Federici, F. (2006). Expression of Penicillium variabile P16 glucose oxidase gene in Pichia pastoris and characterization of the recombinant enzyme. Enzyme Microb. Technol. 39, 1230-1235. doi: 10.1016/j.enzmictec.2006.03.005

Dondero, M., Egaña, W., Tarky, W., Cifuentes, A., and Torres, J. A. (1993). Glucose oxidase/Cqtalase improves preservation of shrimp (Heterocarpus reedi). J. Food Sci. 58, 774-779. doi: 10.1111/j.1365-2621.1993.tb09356.x

European Food Safety Authority (2009). General approach to fish welfare and to the concept of sentience in fish - scientific opinion of the panel on animal health and welfare. Adopted on 29 January 2009. EFSA J. 954, 1-27.

Field, C. E., Pivarnik, L. F., Barnett, S. M., and Rand, A. G. (1986). Utilization of glucose oxidase for extending the shelf-life of fish. J. Food Sci. 51, 66-70. doi: 10.1111/j.1365-2621.1986.tb10837.x

Gao, Z., Li, Z., Zhang, Y., Huang, H., Li, M., Zhou, L., et al. (2012). High-level expression of the Penicillium notatum glucose oxidase gene in Pichia pastoris using codon optimization. Biotechnol. Lett. 34, 507-514. doi: 10.1007/s10529011-0790-6

Ge, L., Zhao, Y. S., Mo, T., Li, J. R., and Li, P. (2012). Immobilization of glucose oxidase in electrospun nanofibrous membranes for food preservation. Food Control 26, 188-193. doi: 10.1016/j.foodcont.2012.01.022

Guo, Y., Lu, F., Zhao, H., Tang, Y., and Lu, Z. (2010). Cloning and heterologous expression of glucose oxidase gene from Aspergillus niger Z-25 in Pichia project administration. All authors contributed to the article and approved the submitted version.

\section{FUNDING}

This work was funded by the National Key Research and Development (R\& D) Program of China (2019YFD0901804).

\section{SUPPLEMENTARY MATERIAL}

The Supplementary Material for this article can be found online at: https://www.frontiersin.org/articles/10.3389/fmicb. 2020.606007/full\#supplementary-material

pastoris. Appl. Biochem. Biotechnol. 162, 498-509. doi: 10.1007/s12010-0098778-6

Han, B., Hou, Y., Jiang, T., Lv, B., Zhao, L., Feng, X., et al. (2018). Computationaided rational deletion of $\mathrm{C}$-terminal region improved the stability, activity, and expression level of GH2 $\beta$-glucuronidase. J. Agric. Food Chem. 66, 11980-11389. doi: $10.1021 /$ acs.jafc.8b03449

Hatzinikolaou, D. G., Hansen, O. C., Macris, B. J., Tingey, A., Kekos, D., Goodenough, P., et al. (1996). A new glucose oxidase from Aspergillus niger: Characterization and regulation studies of enzyme and gene. Appl. Microbiol. Biotechnol. 46, 371-381. doi: 10.1007/s002530050832

ICMSF (1986). “(International commission on microbiological specifications for foods). Sampling plans for fish and shellfish," in Sampling for Microbiological Analysis: Principles and Scientific Applications: ICMSF, Microorganisms in Foods, 2 Edn, Vol. 2, (Toronto, ON: University of Toronto Press), 181-196.

Jeon, Y. J., Kamil, J. Y. V. A., and Shahidi, F. (2002). Chitosan as an edible invisible film for quality preservation of herring and Atlantic cod. J. Agric. Food Chem. 50, 5167-5178. doi: 10.1021/jf0116931

Kalisz, H. M., Hendle, J., and Schmid, R. D. (1997). Structural and biochemical properties of glycosylated and deglycosylated glucose oxidase from Penicillium amagasakiense. Appl. Microbiol. Biotechnol. 47, 502-507. doi: 10.1007/ s002530050963

Kelley, L. A., Mezulis, S., Yates, C. M., Wass, M. N., and Sternberg, M. J. E. (2015). The phyre 2 web portal for protein modeling, prediction and analysis. Nat. Protoc. 10, 845-858. doi: 10.1038/nprot.2015.053

Kohen, A., Jonsson, T., and Klinman, J. P. (1997). Effects of protein glycosylation on catalysis: Changes in hydrogen tunneling and enthalpy of activation in the glucose oxidase reaction. Biochemistry 36, 2603-2611. doi: 10.1021/bi962492r

Kovačević, G., Blažić, M., Draganić, B., Ostafe, R., Gavrović-Jankulović, M., Fischer, R., et al. (2014). Cloning, heterologous expression, purification and characterization of M12 mutant of Aspergillus niger glucose oxidase in yeast Pichia pastoris KM71H. Mol. Biotechnol. 56, 305-311. doi: 10.1007/s12033-0139709-X

Kriaa, M., Hammami, I., Sahnoun, M., Azebou, M. C. H., Triki, M. A. 1, and Kammoun, R. (2015). Purification, biochemical characterization and antifungal activity of a novel Aspergillus tubingensis glucose oxidase steady on broad range of $\mathrm{pH}$ and temperatures. Bioprocess Biosyst. Eng. 38, 2155-2166. doi: 10.1007/s00449-015-1455-y

Kusai, K., Sekuzu, I., Hagihara, B., Okunuki, K., Yamauchi, S., and Nakai, M. (1960). Crystallization of glucose oxidase from Penicillium amagasakiense. BBA - Biochim. Biophys. Acta 40, 555-557. doi: 10.1016/0006-3002(60)91406-2

Li, P., Anumanthan, A., Gao, X. G., Ilangovan, K., Suzara, V. V., Düzgüneş, N., et al. (2007). Expression of recombinant proteins in Pichia pastoris. Appl. Biochem. Biotechnol. 142, 105-124. doi: 10.1007/s12010-007-0003-x

Liu, D., Liang, L., Xia, W., Regenstein, J. M., and Zhou, P. (2013). Biochemical and physical changes of grass carp (Ctenopharyngodon idella) fillets stored at -3 and $0{ }^{\circ}$ C. Food Chem. 140, 105-114. doi: 10.1016/j.foodchem.2013.02.034

Liu, M., Gong, Y., Sun, H., Zhang, J., Zhang, L., Sun, J., et al. (2020c). Characterization of a novel chitinase from sweet potato and its fungicidal effect 
against Ceratocystis fimbriata. J. Agric. Food Chem. 68, 7591-7600. doi: 10.1021/ acs.jafc.0c01813

Liu, Z., Ning, C., Yuan, M., Yang, S., Wei, X., Xiao, M., et al. (2020a). High-level expression of a thermophilic and acidophilic $\beta$-mannanase from Aspergillus kawachii IFO 4308 with significant potential in mannooligosaccharide preparation. Bioresour. Technol. 295:122257. doi: 10.1016/j.biortech.2019. 122257

Liu, Z., Yuan, M., Zhang, X., Liang, Q., Yang, M., Mou, H., et al. (2020b). A thermostable glucose oxidase from Aspergillus heteromophus CBS 117.55 with broad pH stability and digestive enzyme resistance. Protein Expr. Purif. 176, 105717. doi: 10.1016/j.pep.2020.105717

López-Luna, J., Vásquez, L., Torrent, F., and Villarroel, M. (2013). Short-term fasting and welfare prior to slaughter in rainbow trout, Oncorhynchus mykiss. Aquaculture 400-401, 142-147. doi: 10.1016/j.aquaculture.2013.03.009

Macauley-Patrick, S., Fazenda, M. L., McNeil, B., and Harvey, L. M. (2005). Heterologous protein production using the Pichia pastoris expression system. Yeast 22, 249-270. doi: 10.1002/yea.1208

Massa, S., Petruccioli, M., Brocchi, G. F., Altieri, C., Sinigaglia, M., and Spano, G. (2001). Growth inhibition by glucose oxidase system of enterotoxic Eseherichia coli and Salmonella derby: in vitro studies. World J. Microbiol. Biotechnol. 17, 287-291. doi: 10.1023/A:1016690214114

Morsy, M. K., Elsabagh, R., and Trinetta, V. (2018). Evaluation of novel synergistic antimicrobial activity of nisin, lysozyme, EDTA nanoparticles, and/or ZnO nanoparticles to control foodborne pathogens on minced beef. Food Control 92, 249-254. doi: 10.1016/j.foodcont.2018.04.061

Ocaño-Higuera, V. M., Maeda-Martínez, A. N., Marquez-Ríos, E., CanizalesRodríguez, D. F., Castillo-Yáñez, F. J., Ruíz-Bustos, E., et al. (2011). Freshness assessment of ray fish stored in ice by biochemical, chemical and physical methods. Food Chem. 125, 49-54. doi: 10.1016/j.foodchem.2010.08.034

Ojagh, S. M., Rezaei, M., Razavi, S. H., and Hosseini, S. M. H. (2010). Effect of chitosan coatings enriched with cinnamon oil on the quality of refrigerated rainbow trout. Food Chem. 120, 193-198. doi: 10.1016/j.foodchem.2009.10.006

Omar, M. I. V. (1998). Utilization of Sodium Metabisulphite for Preservation of Frozen-Thawed Shrimp (Pandaleus Borealis). Reykjavik: United Nations University Fisheries Training Programme, 1-16.

Pluschkell, S., Hellmuth, K., and Rinas, U. (1996). Kinetics of glucose oxidase excretion by recombinant Aspergillus niger. Biotechnol. Bioeng. 51, 215-220. doi: 10.1002/(sici)1097-0290(19960720)51:2<215::aid-bit11>3.0.co;2-1

Roy, H. (2009). Tuning the properties of the bacterial membrane with aminoacylated phosphatidyl glycerol. IUBMB Life 61, 940-953. doi: 10.1002/ iub. 240

Sukhacheva, M. V., Davydova, M. E., and Netrusov, A. I. (2004). Production of Penicillium funiculosum 433 glucose oxidase and its properties. Appl. Biochem. Microbiol. 40, 25-29. doi: 10.1023/B:ABIM.0000010346.47923.6c

Sun, X., Hong, H., Jia, S., Liu, Y., and Luo, Y. (2020). Effects of phytic acid and lysozyme on microbial composition and quality of grass carp (Ctenopharyngodon idellus) fillets stored at $4^{\circ} \mathrm{C}$. Food Microbiol. 86:103313. doi: $10.1016 /$ j.fm.2019.103313

Tang, H., Yao, B., Gao, X., Yang, P., Wang, Z., and Zhang, G. (2016). Effects of glucose oxidase on the growth performance, serum parameters and faecal microflora of piglets. S. Afr. J. Anim. Sci. 46, 14-20. doi: 10.4314/sajas. $\mathrm{v} 46 \mathrm{i} 1.2$

Trott, O., and Olson, A. J. (2010). Autodock vina: improving the speed and accuracy of docking with a new scoring function, efficient optimization, and multithreading. J. Comput. Chem. 31, 455-461.

Tu, T., Wang, Y., Huang, H., Wang, Y., Jiang, X., Wang, Z., et al. (2019). Improving the thermostability and catalytic efficiency of glucose oxidase from Aspergillus niger by molecular evolution. Food Chem. 281, 163-170. doi: 10. 1016/j.foodchem.2018.12.099

Uchima, C. A., Tokuda, G., Watanabe, H., Kitamoto, K., and Arioka, M. (2012). Heterologous expression in pichia pastoris and characterization of an endogenous thermostable and high-glucose-tolerant $\beta$-glucosidase from the termite Nasutitermes takasagoensis. Appl. Environ. Microbiol. 78, 4288-4293. doi: 10.1128/AEM.07718-11

Van Burik, J. A. H., Schreckhise, R. W., White, T. C., Bowden, R. A., and Myerson, D. (1998). Comparison of six extraction techniques for isolation of DNA from filamentous fungi. Med. Mycol. 36, 299-303. doi: 10.1046/j.1365-280X.1998. 00161.x

Wang, L., Liu, F., Jiang, Y., Chai, Z., Li, P., Cheng, Y., et al. (2011). Synergistic antimicrobial activities of natural essential oils with chitosan films. J. Agric. Food Chem. 59, 12411-12419. doi: 10.1021/jf203165k

Witt, S., Singh, M., and Kalisz, H. M. (1998). Structural and kinetic properties of nonglycosylated recombinant Penicillium amagasakiense glucose oxidase expressed in Escherichia coli. Appl. Environ. Microbiol. 64, 1405-1411. doi: 10.1128/aem.64.4.1405-1411.1998

Xu, D., Sun, L., Li, C., Wang, Y., and Ye, R. (2018). Inhibitory effect of glucose oxidase from Bacillus sp. CAMT22370 on the quality deterioration of Pacific white shrimp during cold storage. LWT Food Sci. Technol. 92, 339-346. doi: 10.1016/j.lwt.2018.02.025

Yamaguchi, M., Tahara, Y., Nakano, A., and Taniyama, T. (2007). Secretory and continuous expression of Aspergillus niger glucose oxidase gene in Pichia pastoris. Protein Expr. Purif. 55, 273-278. doi: 10.1016/j.pep.2007.05.006

Yoo, W., and Rand, A. G. (1995). Antibacterial effect of glucose oxidase on growth of Pseudomonas fragi as related to pH. J. Food Sci. 60, 868-871. doi: 10.1111/j. 1365-2621.1995.tb06249.x

Yu, D., Li, P., Xu, Y., Jiang, Q., and Xia, W. (2017). Physicochemical, microbiological, and sensory attributes of chitosan-coated grass carp (Ctenopharyngodon idellus) fillets stored at $4^{\circ}$ C. Int. J. Food Prop. 20, 390-401. doi: 10.1080/10942912.2016.1163267

Conflict of Interest: The authors declare that the research was conducted in the absence of any commercial or financial relationships that could be construed as a potential conflict of interest.

Copyright (C) 2020 Yuan, Ning, Yang, Liang, Mou and Liu. This is an open-access article distributed under the terms of the Creative Commons Attribution License (CC BY). The use, distribution or reproduction in other forums is permitted, provided the original author(s) and the copyright owner(s) are credited and that the original publication in this journal is cited, in accordance with accepted academic practice. No use, distribution or reproduction is permitted which does not comply with these terms. 